\title{
WANITA MAYORITAS DI NERAKA, IMPERFEK AKAL DAN AGAMA: Antara Polemik, Solusi Dan Motivasi
}

\author{
Fadhilah Is \\ Program Studi Ilmu Hadis, Fakultas Ushuluddin dan Studi Islam UIN Sumatera Utara \\ Jl. Williem Iskandar, Pasar V, Kenangan Baru, Medan Estate, Percut Sei Tuan, 20371 \\ Sumatera Utara, Indonesia \\ Email: fadhilahis575@gmail.com
}

\begin{abstract}
Discourses hadith about women become important among the orientalists and feminist. They describe that Islam made dichotomy for women as second class in public. Hadith narrated by Imam al-Bukhāri that women will be the most widely go the hell, because of their anathema and disobedient to their husbands, and lack of logic and lay in religion. Lafaz this hadith either textual or contextual none contain elements of misogynistic, patriarchal, dichotomies, and degrading women. On the contrary, the spirit motivate women to seek knowledge, worship, obedient, alms and keep oral. Actually, the women shortage become the excess that God has given them, in order to complete each other between a pair of human beings, men and women.
\end{abstract}

Keywords: Feminist, Misogynistic, Lack of Logic, Lay in Religion

\begin{abstract}
Abstrak
Hadis tentang wanita adalah objek yang intens dikomentari oleh para orientalis dan feminis. Mereka mendeskripsikan bahwa Islam mendikotomikan dan menjustifikasi wanita sebagai second public. Hadis yang diriwayatkan Imam Al-Bukhārī bahwa wanita adalah yang paling banyak menghuni neraka, karena banyak melaknat dan banyak mengingkari pemberian suami, dan kurangnya akal dan lemahnya agama wanita. Lafaz hadis ini baik tekstual ataupun konstektual tidak ada mengandung unsur misoginis, patriakhi, dikotomi, dan merendahkan wanita. Malah sebaliknya, memotivasi wanita untuk semangat menuntut ilmu, beribadah, takarub, bersedekah dan menjaga lisan. Di balik kekurangan wanita, sejatinya itulah kelebihan yang Allah berikan kepada mereka, agar saling melengkapi di antara sepasang manusia, laki-laki dan wanita.
\end{abstract}

Kata Kunci: Feminis, Misoginis, Kurang Akal, Kurang Agama

\section{Pendahuluan}

Hadis sebagai sumber landasan

hukum yang kedua setelah Alquran, memiliki substansi yang sangat urgen.

Semenjak masa Rasulullah saw. sampai zaman modern ini para musuh Islam, berusaha mengeluarkan statement untuk menyudutkan hadis Rasulullah Saw. dengan mempertanyakan keotentikan-nya. Akibat-nya muncullah kelompok inkar sunnah, yang meyakini bahwa sumber hukum Islam hanya Alquran saja dan Hadis tidak bisa dijadikan sebagai landasan hukum karena dikeragui keotentikannya serta banyak makna hadis yang bertentangan dengan Alquran itu sendiri.

Saat sekarang ini yang sering mengkritisi hadis Rasulullah Saw. adalah dari kalangan orientalis dan Feminis. Sebagian mereka menganggap Islam mendikotomikan dan men-jastifikasi wanita sebagai second public. Banyak lafal hadis baik secara tekstual ataupun konstektual yang mengandung unsur misoginis, 
patriakhi, dikotomi, dan merendahkan wanita. Di antaranya adalah hadis sahih yang termuat dalam kitab al-Kutub alSittah, seperti hadis wanita mayoritas penduduk neraka serta imperfek akal dan agama, wanita pembawa sial, wanita menyerupai setan, wanita pembatal salat dan sebagainya.

Hakikatnya Islam telah mengangkat posisi wanita ke derejat lebih tinggi, memberikan kebebasan, kehormatan dan hak pribadinya secara merdeka, derajat dan martabat wanita sesuai dengan fitrahnya dan selaras dengan hak dan kewajiban masing-masing. Di dalam Islam tidak ada perbedaan gender di mata Allah, Islam tidak membedakan di antara manusia kecuali derajat ketakwaannya.

Dalam tulisan ini penulis akan membahas hadis tentang wanita mayoritas penduduk neraka serta akal dan agamanya imperfek. Penulis akan mengkaji takhrīj hadis tersebut, pandangan orientalis dan feminis dalam memahami teks hadis, bantahan dari Alquran, Hadis itu sendiri dan pandangan serta tanggapan ulama klasik dan modern dalam memahami secara tekstual dan konstektual hadis ini.

\section{Teks Hadis}

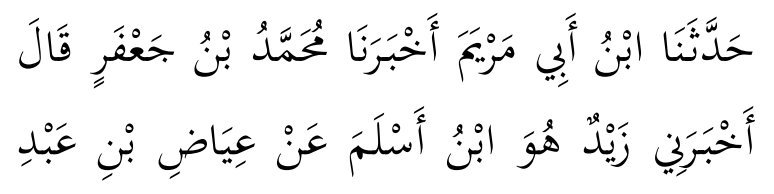

اللَّهِ عَنْ أَبَي سَعِيدٍ الخُنْدُرِيِّ رَضِيَ اللَّهُ عَنْهُ خَرَجْ

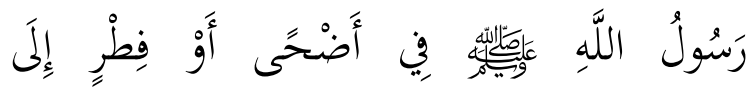

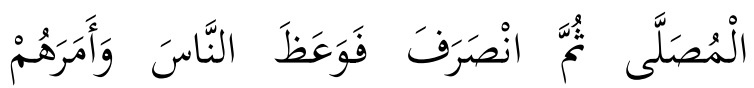

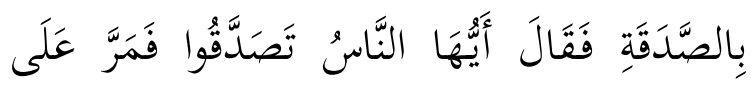

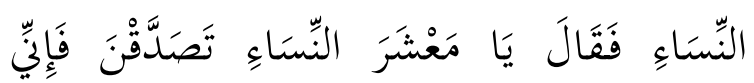

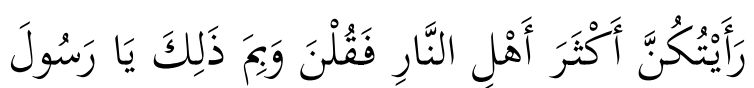
اللَّهِ قَالَ تُكْثِرْنَ اللَّْْنَ وَتَكْفُرْنَ الْعَشِيرَ مَا رَأَيْتِ مِنْ نَاقِصَاتِ عَقْلِ وَدِينٍ أَذْهَبَ رِلْبَِِ الرَّجُلِ

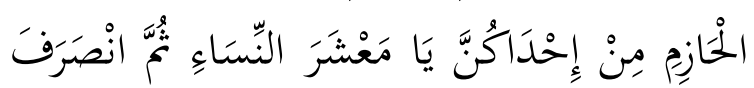

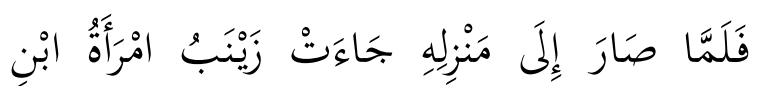
مَسْعُوٍٍٍ تَسْتَأْذِنْ عَلَيْهِهِ فَقِيلَ يَا رَسُولَ اللَّهِ هَذِِهِ

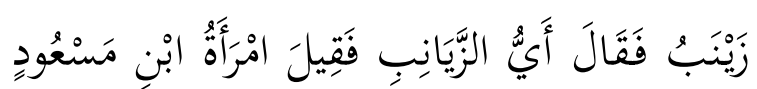

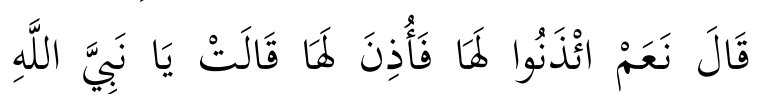

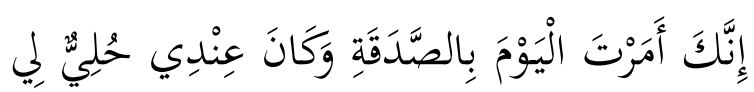

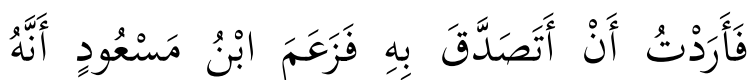

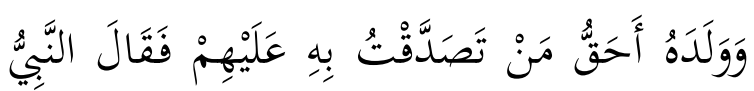

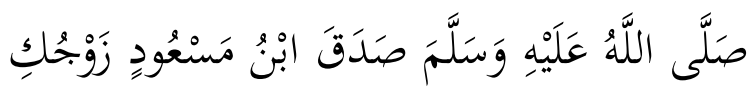

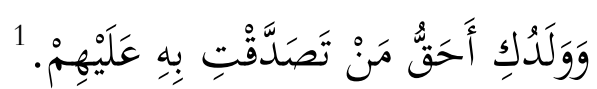

${ }^{1} \mathrm{Abū}$ 'Abdullāh Muhammad bin Ismā'îl bin Ibrāhīm bin al-Mugīrah al-Ju'fì al-Bukhārī, al-Jāmi ' al-Musnad al-Ṣah̄h al-Mukhtașar min Umūri Rasūl șallallāhu 'Alayhi wa Sallam min Sunanihi wa Ayyāmihi, kitab al-Zakāh, bab al-Zakāt 'Alā alQārib, juz 2 (Beirut: Dār Ibnu Kas̄īir, 1987), 531. Dikuatkan dengan kitab al-Hayd, bab Tarku al-Hāyd al-Ṣawma, juz 2, halaman 116. Abū al-Husayn Muslim bin al-Hajjjāj al-Qusyayrī al-Naysābūrī, Sahịh Muslim, kitab al-İmān, bab Bayān Nuqsāān alImān bi Naqs al-Tāa 'ât, juz 1 (Beirut: Dār Ihyā' alTurāis al-'Arabī, t.th.), 86. Muḥammad bin 'Īsā Abū 'Īsā al-Tirmiz̄ì, Al-Jāmi' al-Ṣahīh Sunan al-Timizì̄, kitab İmān 'an Rasūilillāh, bab Istikmāl al-İmān wa Ziyādatihi wa Nuqșānihi, juz 5 (Beirut: Dār al-Iḥya' 
Menceritakan kepada kami Ibnu Abì Maryam mengabarkan kepada kami Muhammad bin Ja'far dia berkata mengabarkan kepadaku Zayd dia adalah Ibnu Aslam dari 'Iyād bin 'Abdillāh dari Abī Sa 'ìd al-Khudrī ra. bahwasannya Rasulullah saw. keluar menuju lapangan tempat salat untuk melaksanakan salat Idul Adha atau Idul Fitri. Setelah selesai beliau memberikan nasehat kepada manusia dan memerintahkan mereka untuk menunaikan zakat seraya berkata: "Wahai manusia, bersedekahlah". Kemudian beliau mendatangi jemaah wanita lalu bersabda: "Sungguh aku melihat kalian adalah yang paling banyak akan menjadi penghuni neraka". Mereka bertanya: "Mengapa begitu wahai Rasulullah saw. ? Beliau menjawab:" "Kalian banyak melaknat dan mengingkari pemberian suami. Tidaklah aku melihat orang yang lebih kurang akal dan agamanya melebihi seorang dari kalian, wahai para wanita." Kemudian beliau mengakhiri khutbahnya lalu pergi. Sesampainya beliau ditempat tinggalnya, datanglah Zaynab, istri Ibnu Mas' $\bar{u} d$ meminta izin kepada beliau, lalu dikatakan kepada beliau, "wahai Rasulullah saw. ini adalah Zaynab." Beliau bertanya: "Zainab siapa?". Dikatakan: "Zainab isteri Ibnu Mas'ūd." Beliau berkata:"Oh ya, persilahkan dia." Maka dia diizinkan kemudian berkata: "Wahai Nabi Allah, sungguh anda hari ini sudah merintahkan sedekah sedangkan aku memiliki emas yang aku berkehendak menzakatkan-nya, namun Ibnu

al-Turaś al-Arabī, t.th.), 10. Muhammad bin Yazīd Abū 'Abdullāh al-Qazwīnī, Sunan Ibnu Mājah, kitab al-Fitan, bab Fitnah al-Nisa', juz 2 (Beirut: Dār alFikri, t.th.), 1326. Ahmad bin Hanbal Abū Abdullāh al-Syaybān̄̄, Musnad Ahmad bin Hanbal, bab Sayyidah 'Abdullāh bin Mas' '̄ed, juz 1 (Kairo: Mu'assasah Qurțubah, t.th.), 376.
Mas 'ūd bahwa dia dan anaknya lebih berhak terhadap apa yang akan aku sedekahkan ini dibandingkan mereka (mustahiq). Maka Nabi saw. bersabda: "Ibnu Mas' 'ūd benar, suamimu dan anak-anakmu lebih berhak kamu berikan Sadaqah dari pada mereka.

\section{Pelemik Hadis Misoginis}

Hadis ini adalah objek yang intens dikomentari oleh para orientalis dan feminis. Mereka mendeskripsikan bahwa Islam mendikotomikan dan menjustifikasi wanita sebagai second public. ${ }^{2}$ Di antaranya mereka adalah seorang feminis, Fatima Mernissi, ${ }^{3}$ dalam kitabnya Women and Islam, menurut beliau hadis ini mengindikasikan bahwasanya Islam sebagai agama patriakhi, ${ }^{4}$ bias misoginis, ${ }^{5}$ yang

\footnotetext{
2،Āqilah Husayn, al-Mar'ah al-Muslimah wa al-Fikri al-Istisyrāqū (Beirut: Dār Ibnu Hazm, 2004), 125.

${ }^{3}$ Seorang guru besar sosiologi di Universitas Muhammad V Maroko. Dia dilahirkan pada tahun 1941 di Fez, Maroko. Dia banyak menulis dan meneliti. Salah satu karya yang mengantarkannya sejajar dengan penulis-penulis wanita lainnya adalah Beyond the Veil: Male-Female Dynamics in Modern Muslim Society. Fatima Mernissi meraih pendidikan masternya dari Universitas Muhammad V di Rabat pada bidang politik. Program Doktor (S3) dari Universitas Braindes Amerika, pada tahun 1973. Karya-karya Mernissi yang telah dipublikasikan Le Harem Politique (Kebijakan Haram), Le Maroc Raconte PaSes Femmes (Menekan Wanita). Fatimah Mernissi, Beyond the Veil: Male-Female Dynamics in Modern Muslim Society (Beyond The Veil Seks dan Kekuasaan Dinamika Pria dan Wanita dalam Masyarakat Muslim Modern), terj. Mahsyur Abadi, cet. 1 (Surabaya: Al-Fikr, 1997), vi. Fatima Mernissi, The Forgotten Queens of Islam (Ratu-Ratu Islam Yang Terlupakan), terj. Rahma Astute dan Enna Hadi, cet. 1 (Bandung: Mizan, 1994), 4.

${ }^{4}$ Patriakhi ialah ideologi yang kelakian di mana laki-laki dianggap memilki kekuasaan
} 
diadopsi dalam ajaran Islam. Juynboll juga mengatakan hadis-hadis Rasulullah saw. banyak yang merendahkan wanita. ${ }^{6}$ Aminah Wadud juga memusatkan perhatiannya terhadap isu-isu tentang wanita. ${ }^{7}$

Kajian masalah hadis misoginis, menjadi topik yang hangat, seiring dengan pembahasan hak-hak asasi manusia yang tidak hanya berimplikasi pada permasalahan wanita itu sendiri tetapi masuk dalam dataran politik, ekonomi,

superior. Ada realitas kehidupan wanita yang entah sejak kapan sampai hari ini masih berada di sudut dan pinggir-pinggir sosial mereka, dalam realitas ini juga masih dipandang sebagai makhluk Tuhan kelas dua, separoh harga laki-laki dan sering diperlakukan, dengan bahasa yang mungkin agak kasar, setengah budak. Hak-hak mereka selalu dibatasi pada wilayah-wilah kehidupan yang sangat ekslusif dan marjinal yaitu rumah tangga. Perspektif ini terjadi hampir seluruh bangunan kehidupan, sosial politik ekonomi dan lainnya. Tegasnya, hidup dan mati wanita seakan-akan ditentukan oleh orang lain. Dan orang lain itu adalah makhluk yang lebih mengunggulkan dan menghebatkan laki-laki, baik itu laki-laki atau wanita itu sendiri. Lihat pada pengantar kelemahan dan fitnah wanita oleh Husein Muhammad. ed., Amiruddin Arani, Tubuh Seksualitas dan Kedaulatan Wanita, cet. 1 (Jakarta: Rahima, 2002), xi.

${ }^{5}$ Secara bahasa, istilah misoginis ini berasal dari kata misogynist. Miso merupakan kata penyambung yang artinya benci, yaitu lawan dari philo artinya cinta, suka. Misogynia artinya benci kepada wanita. Sedangkan misogynist artinya lakilaki pembenci wanita. Lawan dari misogyny ini ialah philogyny. Osman Raliby, Kamus Internasional, cet. 2 (Jakarta: Bulan Bintang, 1982), 356-410.

${ }^{6}$ Ali Masrur, Teori Common Link G.H.A. Juynboll, cet.1 (Yogyakarta: Lkis, 2007), 81.

${ }^{7}$ Amina Wadud, Quran and Women: Reading the Sacred Text From a Woment's Prespective (Quran Menurut Wanita, Membaca Kitab Suci Dengan Semangat Keadilan), terj. Abdullah Ali, cet. 1 (Jakarta: Serambi, 2006), 25. hokum, ${ }^{8}$ bahkan berimbas pula pada pembahasan agama, termasuk Islam, hingga pada relung-relung keyakinan pribadi pada setiap orang, yang tak ayal menimbulkan perdebatan. ${ }^{9}$

Tokoh-tokoh feminis yang berasal dari Indonesia diantaranya, Zaitun Subhan dengan bukunya, Tafsir Kebencian, Studi Bias Gender dalam Alquran. Siti Musdah Mulia dengan bukunya Muslimah Reformis, Wanita Pembaharu Keagamaan. Masdar F. Mas'udi dengan bukunya Islam dan HakHak Reproduksi Wanita. Mereka semua mempertanyakan kembali kualitas dan pemahaman Hadis yang mereka anggap misoginis.

Salah satu implikasi yang tidak terelakkan adalah isu ini berusaha membongkar dogma-dogma agama, menentang sebagian ayat-ayat Alquran, menghujat hadis-hadis dan melawan setiap ide penerapan hukum Islam dengan alasan ketidaklayakan hukum itu dalam

\footnotetext{
${ }^{8}$ Muhammad 'Imārah, al-Tahrī̄r al-Islāmi li al- Mar'ah al-Rad 'Alā Syubhāt al-Gulāh (Kairo: Dār al-Syurūq, 2001), 5.

${ }^{9}$ Perbedaan laki-laki dan wanita masih menyimpan beberapa masalah, baik dari segi substansi kejadian maupun peran yang diemban dalam masyarakat. Perbedaan anatomi biologis antara keduanya cukup jelas. Akan tetapi efek yang timbul akibat perbedaan itu menimbulkan perdebatan, karena ternyata perbedaan jenis kelamin secara biologis (seks) melahirkan seperangkat konsep budaya. Interpretasi budaya terhadap perbedeaan jenis kelamin inilah yang disebut dengan gender. Lihat lebih lanjut, Nasaruddin Umar, Argumen Kesetaraan Jender, cet. 2 (Jakarta: Paramadina, 2001), 1.
} 
membentengi hak-hak wanita, bahkan jelasjelas dianggap meminggirkan wanita. ${ }^{10}$

\section{Bantahan terhadap Dikotomi Gender dalam Islam}

Hakikatnya hadis ini membuktikan, Islam telah mengangkat derajat dan martabat wanita sesuai dengan fitrahnya. ${ }^{11}$ Setiap makhluk yang Allah ciptakan memiliki hak dan kewajiban tersendiri. Hadis ini tidaklah mendikotomikan dan merendahkan wanita. Akan tetapi sebaliknya memotivasi mereka agar waspada dan menjauhi sifat-sifat yang akan menjerumuskan ke neraka. ${ }^{12}$

Ketika Islam datang ke dunia ini, ia telah mengangkat posisi wanita ke derajat lebih tinggi, memberikan kebebasan, kehormatan dan hak pribadinya secara merdeka. Allah berfirman Q.S. al-Ḥujurāt: 13:

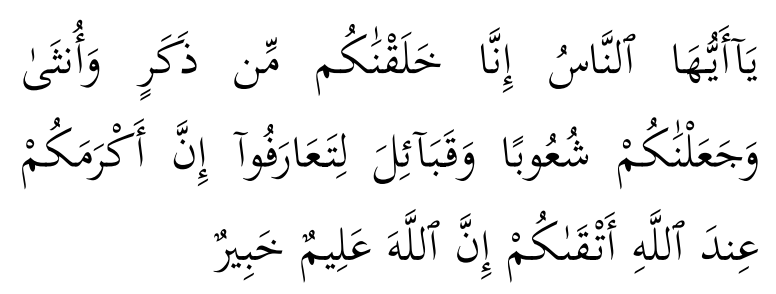

Hai manusia, sesungguhnya Kami menciptakan kamu dari seorang laki-

\footnotetext{
${ }^{10}$ Zaitunah Subhan, Tafsir Kebencian; Studi
Bias Gender dalam Studi al-Ouran (Yogyakarta:

${ }^{10}$ Zaitunah Subhan, Tafsir Kebencian; Studi
Bias Gender dalam Studi al-Quran (Yogyakarta: LKiS, 1999), 1.

${ }^{11}$ Amrū 'Abd al-Karīm Sa'dawī, Qaḍ̄àā alMar'ah fì Fiqh al-Qardāwī (Wanita Dalam Fikih alQaradhawi) (Jakarta: Pustaka al-Kautsar, 2009), 77.

12،Abd al-Halīm Muhammad Abū Syuqqah, Tahrīr al-Mar'ah fì 'Asr al-Risālah, cet. 7 (Kairo: Dār al-Qalām, 2011), 289.
}

laki dan seorang wanita dan menjadikan kamu berbangsa - bangsa dan bersuku-suku supaya kamu saling mengenal. Sesungguhnya orang yang paling mulia di antara kamu di sisi Allah ialah orang yang paling takwa diantara kamu. Sesungguhnya Allah Maha mengetahui lagi Maha Mengenal.

Allah telah memberikan kepada wanita hak untuk memilih baik dalam akidah, pernikahan, dan semua kehidupan lainnya. Bahkan mereka diberikan kebebasan dalam memiliki harta benda, melakukan transaksi jual beli, hibah, dan sebagainya. Pada saat Islam datang, wanita juga telah diberikan bagian dalam mendapatkan warisan ${ }^{13}$. Islam benar-benar telah menjaga hak-hak kaum wanita. Islam menempatkan seorang wanita sebagai ibu, saudara wanita, istri, dan anak dalam posisi yang sangat agung ${ }^{14}$.

Islam yang telah mengakhiri perbudakan terhadap kaum wanita, secara tidak langsung telah memberikan kesempatan bagi mereka untuk mendapatkan kembali kehormatan, kemudian memiliki suami dan anak dalam sebuah naungan keluarga yang utuh. Islam juga telah memberikan hak untuk meminta talak ketika hal tersebut memang harus dilakukan. Islam juga menjaga kehidupan

\footnotetext{
${ }^{13}$ Mutuwalli al-Sya'rawi, Fiqh al-Mar'ah alMuslimah (Fikih Perempuan Busana dan Perhiasan, Sampai Wanita Karier), cet. 3 (Jakarta: Amzah, 2009), 109

${ }^{14}$ Abdul Aziz Matnur, Jangan Rendahkan Wanita (Jakarta: Pustaka al-Kausar, 2009), 79.
} 
kaum wanita dengan memerangi tradisi mengubur anak wanita hidup-hidup sebagai cermin kebencian masyarakat pra-Islam terhadap kaum tersebut, tepatnya pada masa jahiliah. $^{15}$

Hal tersebut merupakan pelajaran yang sangat berharga bagi manusia. Karena secara tidak langsung Islam telah mengajarkan kepada mereka bahwa tidak ada perbedaan antara laki-laki dan wanita. Satu-satunya unsur yang membedakan mereka adalah ketakwaan dan amal saleh.

Wanita memiliki peranan menonjol dalam memperjuangkan Islam dan menyampaikan dakwah sejak Allah mengutus Rasul-Nya dengan membawa petunjuk dan agama yang benar. Apakah sejarah melupakan peranan Khadījah binti Khuwaylid pada masa awal dakwah Islam? Demikian juga dengan Sumayyah Ummu 'Ammar, seorang wanita yang pertama kali mati syahid karena kesabarannya menahan siksaan dengan mempertahankan iman? Atau peranan Asmā' binti Abī Bakr ketika hijrah? Atau peranan Ummu Sulaym pada masa perang Hunayn? Atau peranan Ummahāt al-Mu'minīn dalam kehidupan bersama Rasulullah saw. dan setelah wafatnya? $^{16}$

\footnotetext{
${ }^{15}$ Shalah Qazan, Naḥwa Fikr Nisā'`̄ Harakiyyin Munazzam (Membangun Gerakan Menuju Pembebasan Perempuan) (Solo: Intermedia, 2001), 23.

${ }^{16}$ Mahmūd Mahdī al-Istambulī dan Musțafā Abū Naṣr al-Asyalabī, Nis̄̄' Hawla Rasūl (Mereka
}

Wanita dilihat dari sisi gender adalah adalah seorang manusia yang memiliki hak dan kebebasan dalam berkeyakinan, ia dapat mempergunakan nalarnya dalam berbagai permasalahan yang dihadapinya. Sama persis dengan apa yang dilakukan oleh kaum laki-laki. Dan mereka juga berhak untuk menganggungkan Allah dan beribadah semaksimal mungkin. Di samping itu, wanita juga mendapatkan keistimewaan tertentu yang tidak akan di dapatkan oleh kaum laki-laki, seperti mendapatkan keringanan untuk meninggalkan Salat ketika sedang haid. Kepada wanita, Islam telah memberikan kebebasan berkeyakinan, berpikir dan memilih. ${ }^{17}$

Akan tetapi, meski demikian kita harus menangkap makna dari kata kebebasan dalam pengertian yang benar. Sebab kebebasan tidak dapat kita artikan secara vulgar dan seenaknya. Karena segala kebebasan pasti memilki sebuah aturan.

Apabila memiliki kebebasan dan berkeyakinan tentang sesuatu, maka kebebasan tersebut memiliki keterikatan pada aturan dan undang-undang. Permasalahnya tidak semudah kata-kata yang diucapkan. Karena sebenarnya kebebasan hakiki merupakan ungkapan yang harus dipertanggungjawabkan

Adalah Para Sahabiyyah), cet. 10 (Solo: al-Tibyan, 2010), 38.

${ }^{17}$ Al-Sya'rawi, Fiqh, 116. 
sehingga menjadi sebuah sistem hukum yang rapi dan membuahkan perbuatan yang komprehensif.

Kebenaran dalam memberikan arti kebebasan itu sendiri masih bersifat relatif, sebab tak satu pun komunitas masyarakat menerima kebebasan secara mutlak dan tidak ada satu pun manusia di muka bumi ini yang bisa mengatakan dirinya bebas secara mutlak. Jangan katakan bahwa kebebasan secara mutlak itu ada. Karena kita sendiri tidak akan menjalankan suatu kebebasan orang lain dan orang lain pun tidak akan mendiamkan kita melakukan kebebasan secara mutlak.

\section{Wanita Mayoritas di Neraka?}

Tidak ada satupun ayat dalam Alquran yang menjelaskan bahwa kebanyakan penduduk neraka adalah wanita, namun adanya hadis bahwa wanita mayoritas di neraka, hal ini tidaklah bertentangan dengan akal karena perbandingan wanita dengan laki-laki adalah satu dibandingkan dengan lima puluh, sebagaimana hadis Rasulullah saw.

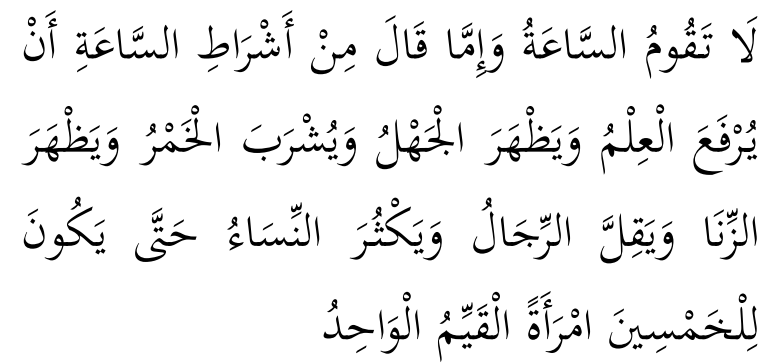

Tidak akan terjadi kiamat sebelum ilmu diangkat, kejahilan mendominasi minuman keras dikonsumsi, zina merajalela, kaum lelaki menjadi sedikit dan kaum wanita menjadi banyak sampai-sampai lima puluh wanita hanya memiliki satu pendamping lelaki. ${ }^{18}$

Walaupun dalam hadis dikatakan wanita mayoritas di neraka bukan berarti minoritas di surga, karena dalam hadis yang diriwayatkan imam Muslim dikatakan bahwa di surga nanti laki-laki akan ditemani oleh dua orang perempuan. Dari hadis ini menunjukkan jumlah wanita di surga lebih banyak dari pada laki-laki. ${ }^{19}$

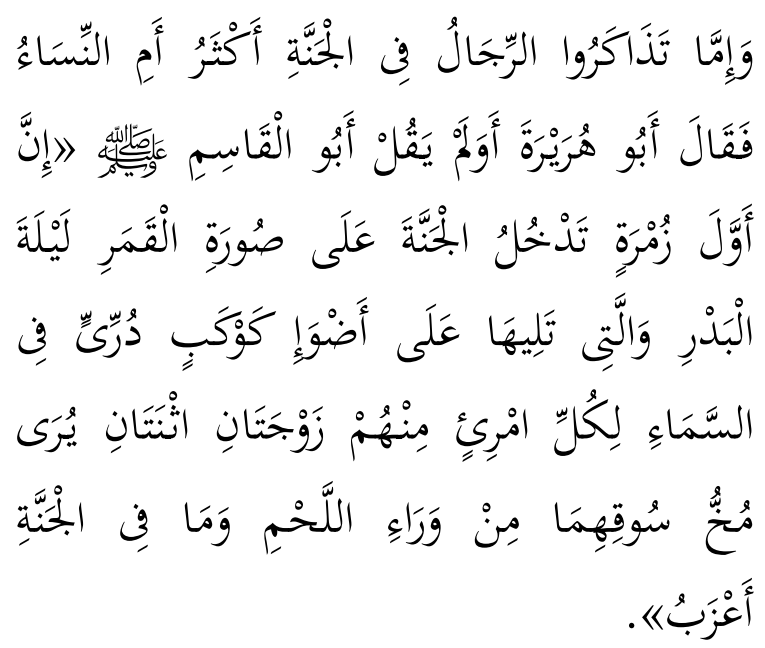

Sekolompok laki-laki dan wanita berdebat siapakah di antara mereka yang akan menjadi penghuni mayoritas di surga. Lalu mereka bertanya kepada Abū Hurayrah mengenai hal itu lalu dia pun menjawab, Rasulullah saw. telah

\footnotetext{
${ }^{18}$ Al-Bukhārī, Șaḥịh, bab Ism al-Jannah, 2497, nomor hadis 6423.

${ }^{19}$ Al-Nawawī, al-Minhāj, juz 9 (Beirut: Dār Ihya' al-Turās̀ al-Arabī, 1392 H), 216. Ibnu Hajar al'Asqalānī, Fath al-Bārī, juz 6 (Beirut: Dār al-Fikr, t.th.), 325. Badr Al-'Ayn̄̄, 'Umdah al-Qārī, juz 4

(Mesir: Multaqā Aḥl al-Hadīis, 2006), 23.
} 
bersabda: Sesungguhnya kelompok pertama yang memasuki surga memiliki rupa seperti bulan pada malam purnama dan kelompok kedua yang mengiringinya seperti bintang yang paling terang cahayanya di atas langit. Setiap orang di antara mereka didampingi dua orang istri. Terlihat jelas tulang betis mereka yang terbalut daging dan di surga tidak ada lelaki yang membujang. ${ }^{20}$

Dalam hadis ini menunjukkan bahwa kaum wanita akan menjadi penghuni terbesar di neraka. Hal ini sebagaimana dikatakan imam al-Qurțubī, karena kaum wanita banyak didominasi hawa nafsu, dan kenderungan kepada hiasan dunia yang fana, serta berpaling dari akhirat karena kekurangan akal mereka dan terbuai berbagai godaan yang datang kepada mereka. $^{21}$ Jika mereka menjadi penghuni mayoritas neraka, apakah hal itu berarti nereka menjadi penghuni minoritas di surga? Mengenai hal ini, ada dua pendapat di kalangan ulama sebagian ulama mengatakan bahwa kaum wanita akan mejadi penghuni mayoritas di neraka dan penghuni minoritas di surga. ${ }^{22}$ Pendapat ini didasarkan pada hadis:

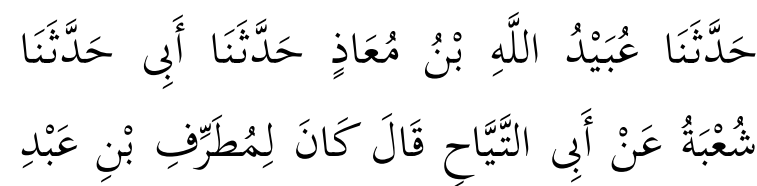

\footnotetext{
${ }^{20}$ Muslim, Sạṇ̄h, bab Awwal Zumrah Tadkhulu al-Jannah.

${ }^{21}$ Al-Mubārakfūrī, Tuḥfah al-Aḥwazī, juz 7 (Beirut: Dār al-Kutub al-Ilmiyyah, t.th.), 276.

${ }^{22}$ Abū Syuqqah, Taḥrīr, 279.
}

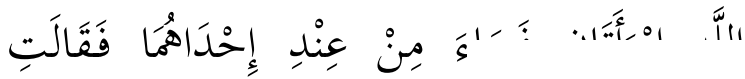

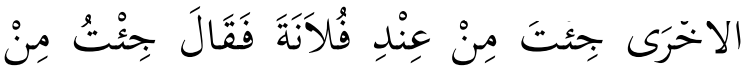

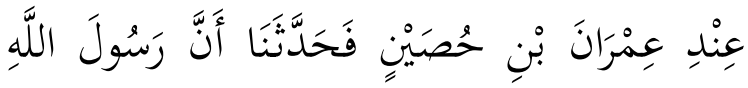

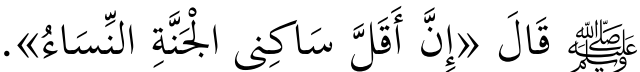
Menceritakan kepada kami, bahwasannya Rasulullah saw. bersabda: "Sesungguhnya penghuni surga yang paling sedikit adalah kaum wanita.

Bisa jadi redaksi hadis ini dari perawi berdasarkan makna yang dipahaminya dari sabda Rasulullah saw. Bahwasannya kaum wanita akan menjadi penghuni terbesar neraka sehingga dia memahami bahwa sebagai konsekuensinya mereka akan menjadi penghuni minoritas di surga. Sementara sudah dijelaskan sebelumnya bahwa keberadaan meraka sebagai penghuni terbesar di surga. ${ }^{24}$ Bisa jadi kaum wanita menjadi penghuni minoritas itu hanya pada tahap awal keberadaan manusia di surga sebelum dikeluarkannya orang-orang yang bermaksiat dari neraka berkat syafaat dari para pemberi syafaat.

Sebagian yang lain mengatakan bahwa kaum wanita akan menjadi penghuni mayoritas, baik di neraka maupun di surga. Di antara kelompok ini adalah Abū Hurayrah:

\footnotetext{
${ }^{23}$ Muslim, Șahīh, bab Aksiar Ahl al-Jannah alFuqarā', nomor hadis 7118, juz 8, 88,

${ }^{24}$ Al-Nawawī, al-Minhāj, juz 9, 216. Al'Asqalānī, Fath, juz 6, 325.
} 


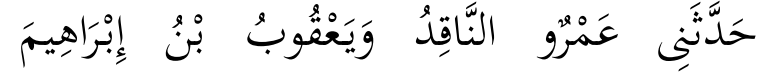

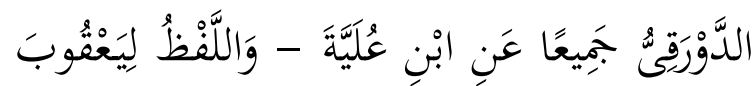

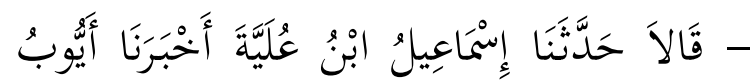

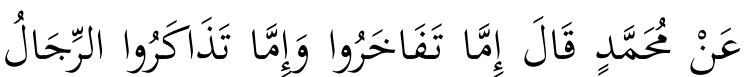

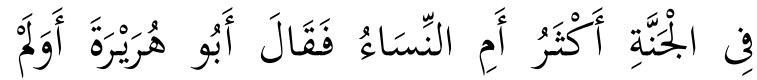

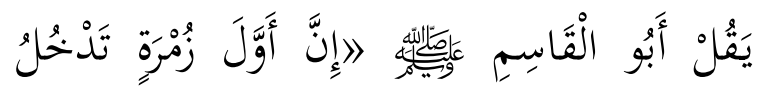

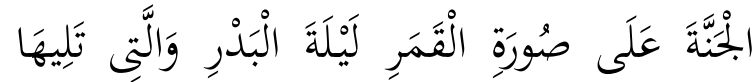

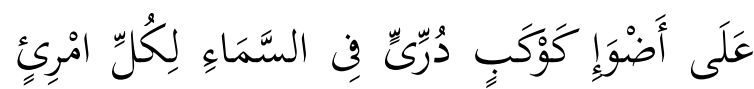

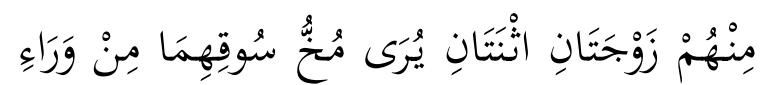

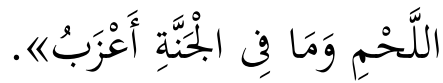

Sekolompok laki-laki dan wanita berdebat siapakah diantara mereka yang akan menjadi penghuni mayoritas di surga. Lalu mereka bertanya kepada Abū Hurayrah mengenai hal itu lalu dia pun menjawab, Rasulullah telah bersabda: Sesungguhnya kelompok pertama yang memasuki surga memiliki rupa seperti bulan pada malam purnama dan kelompok kedua yang mengiringinya seperti bintang yang paling terang cahayanya di atas langit. Setiap orang di antara mereka didampingi dua orang istri. Terlihat jelas tulang betis mereka yang terbalut daging dan di surga tidak ada lelaki yang membujang. ${ }^{25}$

Dengan hadis ini, Abū Hurayrah ra. berhujah bahwa kaum wanita lebih banyak dari kaum pria di surga nanti. Minimal jumlah kaum wanita dua kali lipat dari

${ }^{25}$ Muslim, Sạịḥ, bab Awwal Zumrah Tadkhulu al-Jannah, juz 8, nomor hadis 7325, 145. jumlah kaum pria karena setiap satu pria ada dua wanita yang mengiringinya.

\section{Akal dan Agama Wanita Imperfek?}

Konteks hadis ini tidak bisa lepas dari hadis yang diriwayatkan oleh Abū Sa ‘̄id al-Khudrī, bahwasannya kaum wanita banyak melaknat dan mudah mengingkari kebaikan suami karena wanita lebih didominasi emosi dan perasaanya daripada nalar dan logikanya. Kemudian Rasulullah saw. tambahkan bahwa wanita memiliki akal dan agama yang tidak sempurna. ${ }^{26}$ Sebagaimana sabda Rasulullah saw.

حَلَّتَنَا سَعِيدُ بْنُ أَبْي مَرْيَمَ قَالَ أَخْبَرَنَا عُحَمَّدُ بْنُ

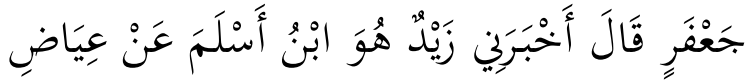

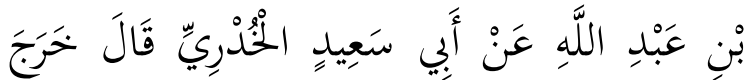

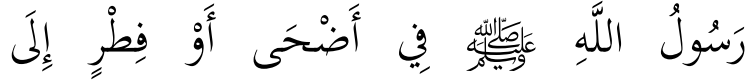

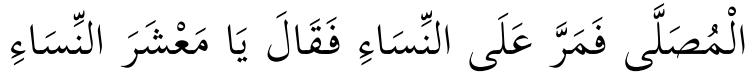

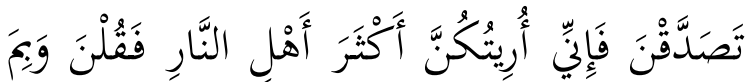

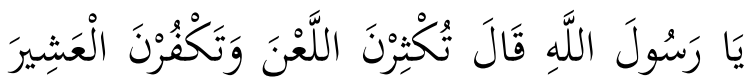

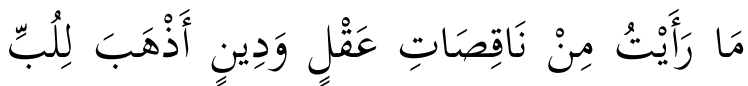

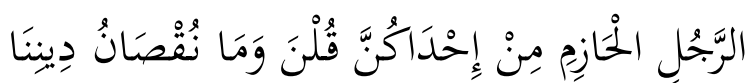

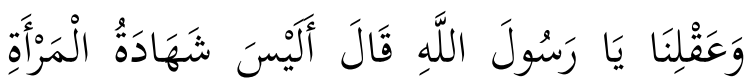
مِثْلَ نِصْفِ شَهَادَةِ الرَّجُل قُلْنَ بَلَى قَالَ فَذَلَكِكِ

${ }^{26}$ 'Ibnu 'Abd al-Bārr, Tamhīd, juz 3 (Magribi: Wizārah 'Umūm al-Awqāf wa al-Syu'ūn alIslāmiyyah, 1387 M), 323-326. Ibnu Bațal, Syarh Șahīh al-Bukhārī, juz 1 (Riyad: Maktabah al-Rusyd, 2002), 175. Al-Syawkān̄i, Nayl al-Auțār, juz 6 (Mesir, Idārah at-Ṭabā'ah al-Munīrah, t.th.), 48. 


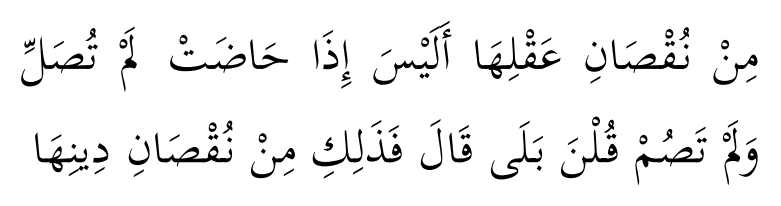

Abū Sa'ìd al-Khudrī ia berkata, "Rasulullah șallallāhu 'alayhi wasallam pada hari raya Idul Adha atau Fitri keluar menuju tempat salat, beliau melewati para wanita seraya bersabda: "Wahai para wanita! Hendaklah kalian bersedekahlah, sebab diperlihatkan kepadaku bahwa kalian adalah yang paling banyak menghuni neraka." Kami bertanya, "Apa sebabnya wahai Rasulullah?" beliau menjawab: "Kalian banyak melaknat dan banyak mengingkari pemberian suami. Dan aku tidak pernah melihat dari tulang laki-laki yang akalnya lebih cepat hilang dan lemah agamanya selain kalian." Kami bertanya lagi, "Wahai Rasulullah, apa tanda dari kurangnya akal dan lemahnya agama?" Beliau menjawab: "Bukankah persaksian seorang wanita setengah dari persaksian laki-laki?" Kami jawab,

"Benar." Beliau berkata lagi: "Itulah kekurangan akalnya. Dan bukankah seorang wanita bila dia sedang haid dia tidak salat dan puasa?" Kami jawab, "Benar." Beliau berkata: "Itulah kekurangan agamanya.,"27

Wanita memiliki tabiat khusus untuk menjalankan tugas-tugasnya. Maka wanita diciptakan untuk memiliki organ tubuh yang cenderung lemah, dikarenakan ia tidak diciptakan untuk berjuang melawan arus kehidupan dan mencari rezeki seperti yang dilakukan oleh kaum lelaki. Secara penciptaan, wanita memang memiliki porsi emasional yang lebih besar dibanding laki-

${ }^{27}$ Al-Bukhārī, al-Jāmi', kitab al-Hayd, bab Tark al-Hāyd al-Sawma, juz 2, 116. laki. Dan ini bukanlah sebuah nilai negatif, melainkan adalah sisi positif yang justru membantunya nanti dalam menjalankan tugasnya sebagai seorang istri dan ibu. ${ }^{28}$

Perkataan Rasulullah saw. sendiri yang mengatakan bahwa wanita itu kurang dari sisi nalar dan agamanya mengindikasikan bahwa wanita akan melakukan berbagai hal dengan mengedepankan sisi emasionalnya serta mengesampingkan sisi nalarnya. Jadi hadis Rasulullah saw. ini yang mengatakan bahwa wanita dinilai kurang akal dan agama, pada hakikatnya merupakan suatu interpretasi dan penggambaran tentang hukum alam yang berlaku bagi kaum wanita, dan bukan merupakan kekurangan atau sesuatu yang tercela. ${ }^{29}$

Seandainya interpretasi hadis di atas bukan seperti itu, tentu saja Rasulullah saw. tidak akan mengambil pendapat Ummu Salamah ra., dalam perjanjian Hudaybiyah. Dan tentu saja Rasulullah tidak mengatakan: "Ambilah setengah agamamu dari wanita berwajah kemerah-merahan (sambil menunjuk kepada 'A' 'isyah binti Abī Bakar ra. Karena pada waktu itu wajah 'A'isyah memang cenderung kemerahmerahan."

\footnotetext{
${ }^{28}$ Al-Sya 'rāwi, Fiqh, 124.

${ }^{29}$ Fakhruddin Nursyam, Hadis-Hadis Pilihan Untuk Wanita (Bandung: Sigma Publishing, 2011), 130.
} 
Maka siapa yang memahami hadis ini sebagai celaan terhadap kaum wanita, maka itu merupakan pengertian yang salah besar. Sebab, maksud hadis ini adalah gambaran bahwa kedua jenis makhluk Tuhan memiliki tugasnya masing-masing dalam kehidupan dan keduanya diciptakan Allah sesuai dengan tugas dan kewajibannya. Ketika seorang laki-laki ditugaskan untuk bekerja mencari rezki, maka ia dituntut untuk mengaktifkan sisi nalarnya dibanding sisi emosinya, karena hanya dengan itulah mereka bisa mendapatkan rezeki dan menutup semua kebutuhan keluarganya, adapun kaum wanita, mereka diciptakan untuk memberikan kasih sayang dan pendidikan, karena mereka lebih mampu untuk memberikan kedamaian. Untuk itu kaum wanita senantiasa butuh untuk mengedepankan sisi emosinya, supaya dapat menjalankan tugasnya secara lebih baik. $^{30}$

Akal secara etimologis diambil dari kata (العقال) orang yang menarik unta sekaligus melarang unta tersebut untuk melewati jalan yang bukan jalanannya, dan bahkan menundukkan unta tersebut di bawah kehendak siapa yang menumpanginya. Jika ia dibiarkan bebas begitu saja tanpa dikendalikan, maka unta tersebut akan berjalan kearah yang ia suka.

\footnotetext{
${ }^{30}$ Al-Sya 'rāwi, Fiqh, 127.
}

Setiap ia melihat rumput, dia akan berlari menuju rumput tersebut ke arah kanan dan kiri, sehingga pengendaranya tidak akan pernah sampai ke tempat yang ditujuannya. Jadi tugas pengendali unta itu adalah untuk mengendalikan gerakan unta agar berjalan di jalan yang benar dan diinginkan sehingga jika unta itu menyimpang ke kiri dan ke kanan, maka pengendaranya akan menegur pengendali hewan tersebut agar kembali berjalan di jalan yang benar. ${ }^{31}$

\section{Demikianlah tugas akal yang} bertugas mengendalikan perkara-perkara hawa nafsu agar berjalan pada koridor ajaran Allah. Akal berfungsi untuk memperlihatkan berbagai pandangan dan memilih pendapat yang paling baik. Bencana dalam menentukan setiap pandangan adalah hawa nafsu dan gerakan emosional. Sedangkan wanita memiliki tingkatan emosi dan perasaan yang sangat tinggi. Sebagai imbas dari tugas mulia yang harus diemban seorang wanita yaitu mengandung janin dalam rahimnya dan pengasuh bayi yang tidak mengetahui bagaimana mereka menyampaikan segala keinginannya. Maka seluruh sifat dan karekteristik yang dimiliki oleh wanita adalah emosional dan inilah yang dapat menghancurkan sebuah pendapat. ${ }^{32}$

\footnotetext{
${ }^{31}$ Al-Sya'rāwi, Fiqh, 127.

${ }^{32}$ Al-Sya'rāwi, Fiqh, 127.
} 
Misalkan seorang suami memiliki sedikit uang yang hanya bisa mencukupi kebutuhan rumah tangga sampai akhir bulan, seketika itu salah seorang anaknya datang meminta uang, maka secara otomatis laki-laki tersebut tidak akan memberikannya karena ia telah berpikir dengan akalnya dan tahu bahwa uang yang ia pegang jika berkurang sedikit saja tentu tidak akan mencukupi kebutuhan rumah tangga lainnya. Selanjutnya akan terjadi masalah-masalah baru seandainya anak tersebut tetap memaksa agar uang tersebut diberikan, seorang bapak pasti akan menghardik dan memukulnya. ${ }^{33}$

Kalau saja seorang ibu berada pada posisi bapak tadi dan salah seorang anaknya meminta sesuatu, dengan serta merta ibunya pasti lebih sering akan memberinya tanpa berpikir panjang tentang apa yang harus ia lakukan pada sisa bulan yang ada. Terlebih ketika anaknya itu menangis dan seorang ibu akan mengupayakan uang itu meskipun dengan cara meminjam dari salah seorang tetangganya atau bahkan ia akan pikir untuk bergabung pada salah satu instansi tertentu untuk bekerja dan mendapatkan uang untuk si anak. Ibu itu akan melakukan apa saja untuk memenuhi permintaan anakanaknya. $^{34}$

\footnotetext{
${ }^{33}$ Al-Sya'rāwi, Fiqh, 127.

${ }^{34}$ Al-Sya'rāwi, Fiqh, 127.
}

Seorang ibu akan selalu terdorong untuk memberikan kepuasan kepada anakanaknya. Ia akan meminjam tanpa ia tahu bagaimana dan dari mana ia bisa melunasi utang tersebut? atau bagaimana mencicil tanggungan yang ia pinjam dari tempat kerjanya? Yang ia pikirkan dalam hidupnya hanya bagaimana memberi kepuasan kepada anak-anaknya. ${ }^{35}$

Jelas sekali bahwa cara berpikir seorang wanita sangat dipengaruhi oleh faktor emosional dan bukan rasio. Hasilnya ia tidak akan dapat mengatur segalanya secara rasional dan logis. Selanjutnya akan menimbulkan persoalan baru baginya dan keluarganya. Ini salah satu hikmah mengapa Allah swt memberikan tugas kendali kepada laki-laki dan tugas mengayomi kepada wanita. Semuanya itu supaya perjalanan biduk keluarga dapat tetap kokoh dan seimbang. Seorang bapak merupakan simbol dari akal, logika dan aturan, sementara seorang ibu adalah simbol dari kasih sayang, cinta kasih dan senyuman. Keduanya adalah dua sisi yang sangat penting dalam sebuah sistem kesinambungan itu. ${ }^{36}$

Keduanya adalah dua sisi yang sangat penting dalam sebuah sistem kesinambungan dan keseimbangan. Seluruh anggota lainnya tentu akan memanfaatkan

\footnotetext{
${ }^{35}$ Al-Sya 'rāwi, Fiqh, 127.

${ }^{36}$ Al-Imārah, Tahrī̄r, 90.
} 
keseimbangan itu. Seorang bapak akan memanfaatkan kasih sayang istri dan seorang istri akan memanfaatkan kebijaksanaan akal seorang suami. Sedangkan anak-anak nya adalah anggota keluarga yang dapat mengambil keuntungan dari mereka. Karena mereka telah memanfaatkan rasionalitas bapak dan kasih sayang ibu. Dengan demikian, anak-anak itu akan tumbuh besar secara stabil baik secara fisik dan mental. Dan seandainya dalam interaksi tersebut tergores sedikit luka, tentu akan berpengaruh pada stabilitas dan kekokohan rumah tangga tersebut. ${ }^{37}$

Kekurangan dari sisi agama dikarenakan wanita mengalami haid setiap bulannya, akibatnya Ibadah dan taqarrub kepada Allahpun tidak sama dari segi kuantitasnya dengan laki-laki. Kekurangan dari sisi agama ini tidak identik dengan dosa. Imam Ibnu Hajar berkata; "Kekurangan dari sisi agama tidak hanya terbatas pada tindakan-tindakan yang mengakibatkan dosa," bahkan lebih luas dari pada itu, sebagaimana yang dikatakan Imam al-Nawawī karena kekurangan dari sisi agama ini merupakan sesuatu yang relatif. Sebagai contoh, sesuatu yang sempurna bisa dianggap kurang jika dibandingkan dengan yang lebih sempurna.

\footnotetext{
${ }^{37}$ Muhammad Rasyid al-Uwayyid, Ahâadīs alMar'ah fi Șahīhayn (Hadis-Hadis Perberdayaan Wanita dari Kitab Sahih Bukhari dan Muslim) (Surabaya: Pustaka Yassir, 2014), 60.
}

Begitu pula seorang wanita yang sedang haid dia tidak berdosa dengan meninggalkan salat tetapi dia dianggap kurang jika dibandingkan dengan orang yang menunaikan salat. ${ }^{38}$

Wanita tetap mendapatkan pahala ketika meninggalkan salat karena sedang haid, sebagaimana dimakluminya seseorang yang sakit atau bepergian lalu meninggalkan beberapa ibadah sunnah yang sudah rutin dilaksanakan. Dia akan tetap mendapatkan pahala ibadah tersebut. Rasulullah saw. bersabda:

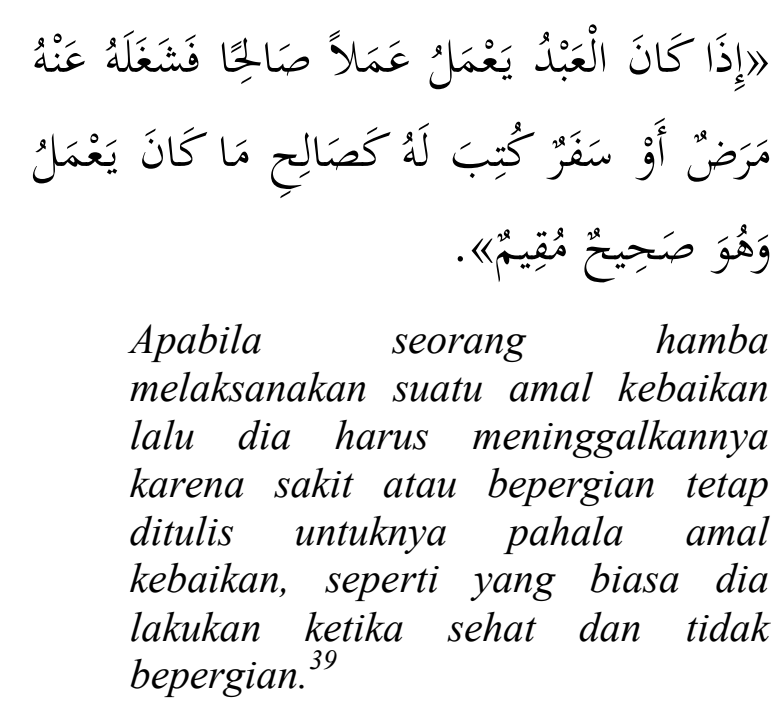

Apakah demikian juga dengan wanita yang sedang haid, imam al-Nawawi berkata; "Zahir hadis ini menunjukkan bahwa wanita yang sedang haid tidak mendapatkan pahala ibadah yang ditinggalkannya. Perbedaan antara orang

\footnotetext{
${ }^{38}$ Al-‘Asqalānī, Fath, juz 1, 407.

${ }^{39}$ Abū Dāwud, Sunan, bab İ̇̄ā Kāna al-'Abd Ya'mal 'Amalan, nomor hadis 14842, juz 2, 200.
} 
yang haid dan orang yang sakit, bahwasannya orang yang sakit melaksanakan suatu ibadah dengan niat melakukannya. Sementara wanita yang haid tidaklah demikian adanya. Dia justru meniatkan diri untuk meninggalkan salat selama masa haid, bahkan haram baginya meniatkan salat selama masa haid tersebut." ${ }^{40}$

Imam Ibnu Hajar berkata; "Terlihat olehku bahwa hal itu termasuk di antara sebab-sebab yang menjadikan kaum wanita sebagai penghuni terbesar di neraka karena mereka telah menjadi faktor yang menyebabkan hilangnya akal seorang pria yang cerdas sehingga dia melakukan sesuatu yang tidak sepantasnya dia ucapkan. Dengan begitu berarti mereka ikut berpartisipasi dalam perbuatan dosa. Gambaran ini terlihat dengan ungkapan Rasulullah saw.: ${ }^{41}$

1. Beliau mengunakan kata superlatif “ażhabu” yang berarti paling dahsyat dalam menghilangkan akal pria.

2. Beliau menggunakan kata "al-lubb" yang berarti sesuatu yang lebih khusus dari akal.

3. Beliau memberikan sifat kepada pria yang diperdaya wanita itu dengan sifat al-Hāzim yang sangat teliti dan seksama dalam berbagai urusannya.

\footnotetext{
${ }^{40}$ Al-Nawawī, Al-Minhāj, juz 2, 68.

${ }^{41}$ Al-'Asqalānī, Fatḥ, juz 1, 407.
}

Semua ini menunjukkan betapa dahsyatnya kekuatan wanita dalam menundukkan dan memperdaya kaum pria. Jika seorang pria yang cerdas, teliti dan seksama dapat ditundukkan, pria yang awam dan lemah akan jauh lebih mudah untuk ditundukkan.

Akan tetapi kalau kita telusuri lafal hadis yang digunakan, bukanlah dipahami secara tekstual yang menunjukkan Rasulullah saw. merendahkan wanita. Rasulullah saw. dengan akhlak yang agung tidak mungkin menyakiti hati sahabatnya ketika hari raya Idul Fitri. Pada hari itu umat Islam bergembira dan bersyukur bahkan Rasulullah saw. menyuruh para wanita untuk datang ke mesjid. Lafaz yang digunakan adalah al-lubb dan al-ḥāzim, maka Rasulullah saw. seakan ta'ajjub dengan kekurangan yang ada pada wanita namun bisa menaklukkan hati laki-laki. ${ }^{42}$

Lafal hadis ini disampaikan Rasulullah saw. melalui tanya jawab. Ini menunjukkan dengan kelembutan Rasulullah saw. seolah-seolah ia ingin mengungkapkan; "Wahai wanita, Allah telah memberikan kepadamu kemampuan untuk menaklukkan hati laki-laki perkasa dan cerdas, walaupun sebenarnya engkau lemah, maka gunakanlah kemampuan itu untuk kebaikan." Hal ini terbukti bagaimana pemimpin dunia dan orang-

\footnotetext{
${ }^{42}$ Nursyam, Hadis, 131.
} 
orang hebat dan sukses tidak terlepas dengan peranan wanita dibelakangnya atau sebaliknya orang-orang hebat dan sukses pada awalnya, tiba-tiba hancur akibat bujukan dan rayuan wanita. Hadis ini sebagai peringatan kepada wanita agar berhati-hati dan memperbanyak ibadah serta memanfaatkan kemampuan ini untuk amar ma'rūf nahī munkar.

Jawaban Rasulullah saw. terhadap pertanyaan yang dilontarkan oleh sahabiyyah menunjukkan bahwa beliau adalah orang yang santun, lembut dan bijaksana. Beliau menjelaskan permasalahan ini dengan menggunakan metode dialog atau tanya jawab sehingga lebih efektif dalam menggugah perhatian dan menanamkan pemahaman mereka. Beliau pun menjelaskan permasalahan ini dengan contoh sesuai dengan kadar intelektual mereka, dengan lemah lembut tanpa mengiringinya dengan celaan atau ungkapan kasar

Dr. Yūsuf al-Qaraḍāwī mengatakan; "Jika Islam telah menganggap derajat wanita sama dengan laki-laki, mengapa Allah melebihkan laki-laki daripada wanita dalam sebagian keadaan, sebagaimana dalam kesaksian, warisan, diyat, kekuasaan dalam rumah tangga, kepemimpinan negara, dan sebagai hukum-hukum parsial lainnya?."43

Pada realitanya, perbedaan laki-laki dalam hukum-hukum ini semua bukan karena laki-laki itu lebih mulia di sisi Allah dan lebih dekat dengan-Nya dari pada wanita. Orang yang paling mulia di sisi Allah adalah orang yang bertakwa baik laki-laki atau wanita. Akan tetapi perbedaan disesuaikan dengan tugas yang secara fitrah sesuai bagi laki-laki dan wanita. ${ }^{44}$

Kesaksian yang dinyatakan dalam ayat tentang hutang piutang, diperintahkan untuk dilakukan secara tertulis dan berhatihati.

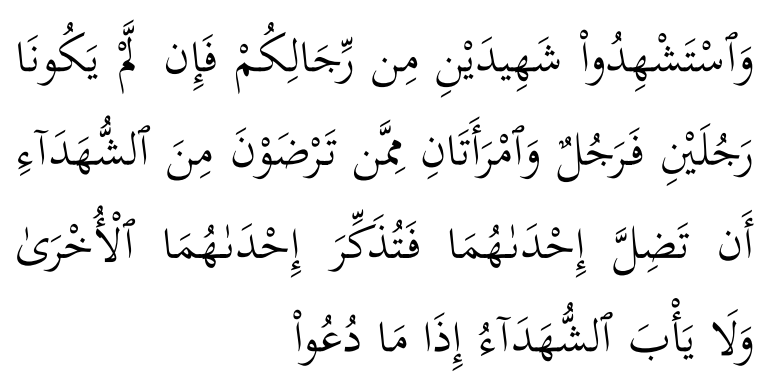

Dan persaksikanlah dengan dua orang saksi dari orang-orang lelaki (di antaramu). Jika tak ada dua oang lelaki, maka (boleh) seorang lelaki dan dua orang perempuan dari saksisaksi yang kamu ridai, supaya jika seorang lupa maka yang seorang mengingatkannya. Janganlah saksisaksi itu enggan (memberi keterangan) apabila mereka dipanggil.

\footnotetext{
${ }^{43}$ Sa'dawi, Qậāyā, 84.

${ }^{44}$ Muhammad Anis Qasim Ja'far, al-Huqūq al-Siyāsiyah li al-Mar'ah fì al-Islām wa al-Fikr wa al-Tasyrī' al-Mu'āṣir (Perempuan dan Kekuasaan Menelusuri Hak Politik dan Persoalan Gender dalam Islam) (Jakarta: Amzah, 2008), 12.
} 
Dengan demikian, Alquran telah menjadikan kesaksian laki-laki sama dengan kesaksian dua wanita, sebagaimana para fukaha juga berpendapat bahwa kesaksian wanita tidak diterima dalam masalah hukum dan kisas. Perbedaan ini bukan dimaksudkan untuk mengurangi kemanusiaan wanita dan kemuliaannya, melainkan karena hal itu merupakan fitrah dan keistimewaannya, sebab wanita biasanya tidak disibukkan dengan urusan harta dan kegiatan perdata, akan tetapi biasanya disibukkan dengan urusan rumah tangga jika dia seorang istri dan urusan anak jika dia seorang ibu, serta sibuk memikirkan menikah jika dia masih gadis. Karena itu keterlibatan wanita dalam muamalah lebih sedikit dari pada laki-laki. Dan untuk itulah, Allah memerintahkan orang-orang yang berpiutang apabila ingin hutang-hutangnya aman agar mereka meminta kesaksian dua orang laki-laki, atau satu orang laki-laki dan dua orang wanita. Alquran menyebutkan alasannya supaya jika seorang lupa maka seorang lagi mengingatkannya. ${ }^{45}$

Di antara sebab mengapa para fukaha tidak menganggap kesaksian wanita dalam masalah hukum hadd dan kisas adalah karena biasanya wanita jauh dari

${ }^{45}$ Abdul Malik Kamal, Fiqh al-Sunnah li anNisa' (Ensiklopedi Fiqih Wanita), cet. 2 (Depok: Pustaka Khazanah Fawa'id, 2017). Sa‘dawi, Qadāyā, 85. masalah-masalah pertikaian yang menyebabkan pada pembunuhan, jauh dari lembah kejahatan dan permusuhan yang dapat menyebabkan hilangnya nyawa, rusaknya kehormatan, dan kerugian pada harta. Bahkan wanita jika dihadapkan pada tindakan kriminal, seringkali dia menutup mata dan lari seraya berteriak ketakutan, sehingga sulit baginya untuk dapat memberikan keterangan yang benar dan teliti terkait tindak kriminal tersebut. Disebabkan itulah para fukaha juga sepakat untuk mengambil kesaksian kaum wanita atas masalah-masalah yang secara khusus hanya mereka yang mengetahuinya, seperti kesaksian dalam menyusui, masalah keperawanan, status janda, haid, melahirkan dan semacamnya yang termasuk masalahmasalah yang hanya diperbolehkan untuk diketahui oleh wanita. ${ }^{46}$

Sekalipun demikian, tidak diterimanya kesaksian wanita dalam masalah hukum hadd dan kisas masih belum menjadi ijmak ulama, karena mazhab Ața' (dari kalangan tabiin) mengambil kesaksian wanita. Sebagian fukaha juga ada yang mengambil kesaksian wanita dalam masalah pidana, biasanya di tempat-tempat yang hanya boleh dimasuki oleh wanita, seperti kamar mandi wanita, kamar tidur

\footnotetext{
46، Aṭiyah Saqar, Fatāwa wa Ahkām lil Mar'ah al-Muslimah (Kairo: Maktabah Wahbah, 2002), 239.
} 
wanita dan tempat lainnya yang dikhususkan untuk wanita. ${ }^{47}$

Jika salah seorang wanita menganiaya wanita yang lain dengan cara membunuh atau melukai, lalu saksi hanya wanita itu sendiri, apakah kesaksian mereka diabaikanhanya karena mereka wanita? Atau tetap diminta kesaksian laki-laki di tempat yang biasanya mereka tidak memasukinya? Menurut pendapat yang sahih, kesaksian mereka diterima selama mereka jujur, terpercaya dan dalam keadaan sadar ketika memberikan kesaksian.

Ibnu al-Qayyim menegaskan bahwa bukti dalan syariat Islam lebih umum dari pada kesaksian, dan setiap bukti yang dapat dipertanggung-jawabkan bisa menjadi pertimbangan hakim dalam mengambil keputusan. Sebab di antaranya, hakim dapat menetapkan hukum sesuai dengan buktibukti dan kesaksian non muslim apabila dapat dipercaya dan membuatnya tenang. ${ }^{48}$

Dianggapnya kesaksian dua orang wanita dalam hutang sama seperti kesaksian satu orang laki-laki bukan untuk melamahkan akalnya yang memang dengannya dia menjadikan manusia yang kurang akal dan berpangaruh baginya, melainkan karena wanita sebagaimana dikatakan oleh Syekh Muhammad 'Abduh tidak berurusan dengan masalah-masalah yang berhubungan dengan transaksi dan semacamnya. Dalam masalah ini ingatan wanita lemah. Akan tidak demikian dalam urusan rumah yang menjadi tugasnya yang mana dalam hal itu dia lebih kuat ingatannya dari pada laki-laki. Tabiat manusia secara umum menginginkan urusan itu diserahkan kepada orang yang yang kuat ingatannya dalam hal itu dan memang menjadi kesibukannya. ${ }^{49}$

Ayat di atas dinyatakan apabila wanita tidak banyak tahu dan tidak menghadiri transaksi hutang piutang serta tidak disibukkan dengan urusan jual beli di pasar, sekalipun memang ada sebagian dari wanita yang memang demikian kesibukkan tanpa menafikan kodratnya sebagai wanita dalam kehidupan. Ayat Alquran tersebut memang menganjurkan kepada kesaksian yang paling sempurna, yaitu kesaksian lakilaki. Akan tetapi apabila dalam suatu lingkungan tertentu, wanita juga disibukkan dengan transaksi jual beli dan menghadiri transaksi hutang piutang, maka mereka juga berhak untuk meminta kesaksian wanita sebagaimana kesaksian laki-laki, selama hal itu membuat mereka tenang dan percaya tidak khawatir lupa seperti pada laki-laki. ${ }^{50}$

\footnotetext{
${ }^{47} \mathrm{Sa}$ 'dawi, Qadāyā, 87.

${ }^{48} \mathrm{Sa}$ 'dawi, Qadāyā, 87.
} 


\section{Motivasi Di Balik Polemik Hadis}

Hadis ini mengindikasikan penyebab wanita mayoritas di nereka di antara adalah:

1. Wanita Suka Melaknat dan Mengingkari Kebaikan Suami

Hadis ini menunjukkan bahwa melaknat dan mengingkari kebaikan suami hukumnya haram dan dosa, termasuk dosa besar. ${ }^{51}$ Bahkan bolehnya memberinya label terhadap tindak kemaksiatan yang tidak mengeluarkan pelakunya dari agama Islam dengan label kufur. Namun yang dimaksudkan adalah kufur kecil yang tidak sampai mengeluarkan pelakunya dari bingkai keislaman. Hal ini dimaksudkan sebagai peringatan yang sangat keras terhadap kaum wanita agar tidak mengingkari kebaikan suaminya. ${ }^{52}$

Disebutkan, "kufra al-'asȳir secara khusus di antara dosa-dosa lainnya karena ada hikmah yang sangat agung, yaitu hak suami atau seorang istri mengiringi hak Allah atas dirinya. ${ }^{53}$ Rasulullah saw. bersabda:

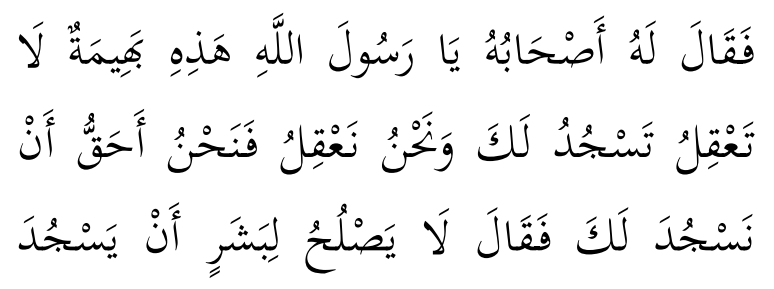

\footnotetext{
${ }^{51}$ Al-Nawawī, al-Minhāj, juz 9, 216.

${ }^{52}$ Al-Mubārakfūrī, Tuhfah, juz 7, 276.

${ }^{53}$ Al-Bārri, al-Tamhìd, juz 3, 323-326.
}

\section{لِبَشَرِ وَلَوْ صَلَحَ لِبَشَرِ أَنْ يَسْجُحَ لِبَشَرِ لَأَمَرْتُ

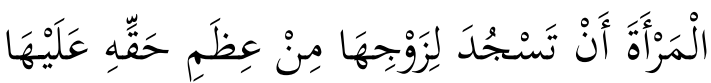 \\ Tidak sepatutnya bagi manusia bersujud kepada sesama manusia. Seandainya patut bagi manusia bersujud kepada sesama manusia, aku akan memerintahkan seorang wanita untuk bersujud kepada suaminya karena besarnya hak-hak suaminya atas dirinya. ${ }^{54}$}

Syukur kepada manusia menjadi indikasi dan penentu syukur seorang hamba kepada Allah. Rasulullah saw. bersabda:

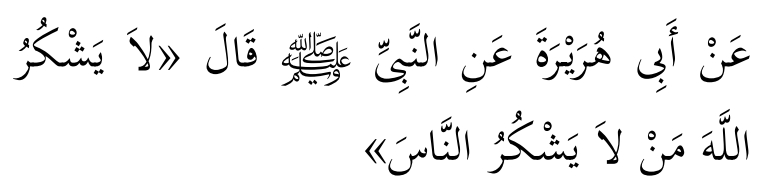

Siapa tidak bersyukur kepada manusia berarti dia tidak bersyukur kepada Allah. ${ }^{55}$

Jadi kalau seorang wanita tidak mensyukuri kebaikan suami berarti tidak mensyukuri nikmat dan anugerah Allah. Faktor-faktor yang menyebabkan sulitnya wanita berterima kasih dengan suaminya:

1. Wanita memandang apa yang diterima dari suami adalah haknya dan sudah menjadi kewajiban suaminya. Jadi untuk apa berterima kasih.

2. Wanita berharap mendapatkan yang lebih dari apa yang diberikan suami. Hendaknya wanita merasa qanā'ah

\footnotetext{
${ }^{54}$ Aḥmad, Musnad, bab Anas bin Mālik, nomor hadis 12635, juz 3, 158.

${ }^{55}$ Al-Tirmiż̀̄, Sunan, bab al-Syukr li man Ahsan Ilayka, nomor hadis 1954, juz 4, 339.
} 
dan merasa cukup dengan apa yang ada.

$$
\begin{aligned}
& \text { عَنْ عَبْدِ اللَّهِ بْنْ عَمْروِ بْنْ الْعَاصِ أَنَّ }
\end{aligned}
$$

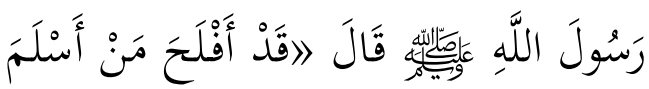

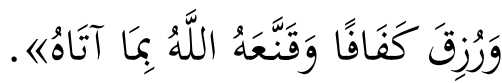

Sesungguhnya beruntung seseorang yang beragama Islam, diberi rezeki yang cukup dan Allah menjadikannya puas dengan apa yang telah diberikan kepadanya. ${ }^{56}$

3. Wanita sulit berterima kasih karena dia tidak memahami hak-hak suami atas dirinya. Dia merasa telah melakukan hak-hak suami sehingga dia menuntut suami untuk menunaikan hak-haknya pula. Sebagaimana sabda Rasulullah saw.
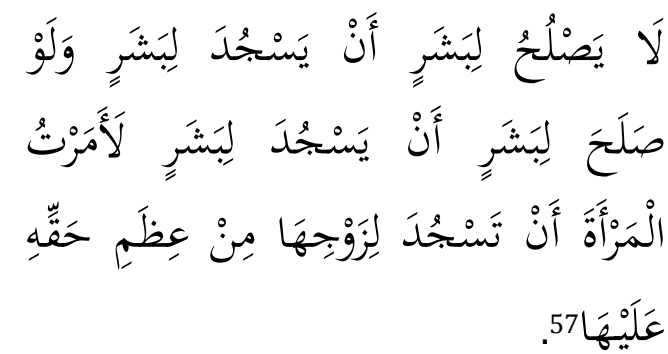

4. Selalu membandingkan dirinya dengan tetangga atau temannya yang lebih kaya, sehingga meremehkan pemberian suaminya.

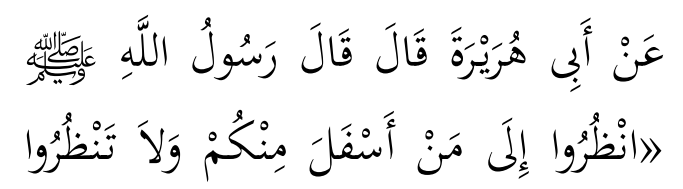

${ }^{56}$ Muslim, Șahīh, bab al-Kafaf wa alQanā'ah, nomor hadis 125, juz 2, 730.

${ }^{57}$ Aḥmad, Musnad, bab Anas bin Mālik, nomor hadis 12635 , juz 3, 158 .

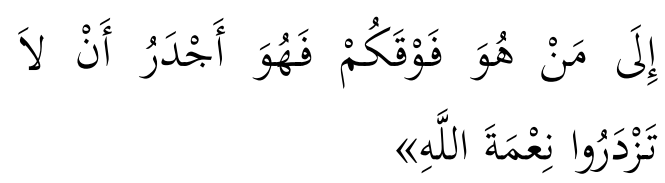

Lihatlah orang yang lebih rendah darimu dan janganlah melihat orang yang berada di atasmu. Hal ini akan membuatmu tidak meremehkan nikmat Allah yang telah diberikan kepadamu. $^{58}$

5. Suka meremehkan sesuatu yang dianggapnya sedikit, sehingga Rasulullah saw. berpesan secara khusus kepada wanita:

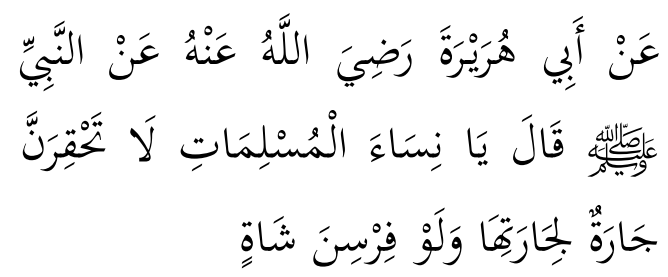

Wahai wanita-wanita muslimah, janganlah seseorang tetangga meremehkan pemberian tetangga lainnya meski itu hanyalah ujung kuku seekor kambing. ${ }^{59}$

6. Mudah melupakan kondisi sulit yang pernah dialaminya, karena bergelimang kenikmatannya sebelumnya seakan-akan dia tidak pernah mengalami kesusahan pada kehidupan sebelumnya. Akibatnya ketika mengalami kesusahan dia sudah berteriak-teriak mengumpat suaminya. Rasulullah bersabda: 


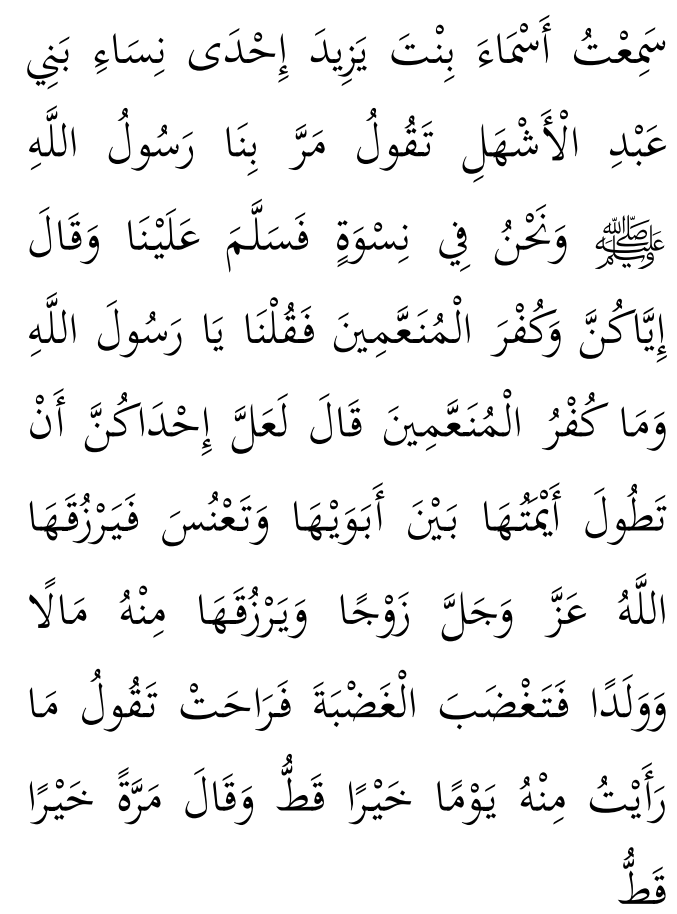

Rasulullah saw. melewati kami, kaum wanita, lalu beliau mengucapkan salam kepada kami dan bersabda, "Jauhilah olehmu pengingkaran orang-orang yang diberi nikmat." Kami bertanya, "Wahai Rasulullah, apa yang dimaksud dengan pengingkaran orang-orang yang diberi nikmat?" Beliau menjawab, "Barangkali ada ada salah seorang di antara kamu yang sudah lama membujang di bawah asuhan ibu bapaknya dan menjadi perawan tua lalu Allah azza wa jalla menganugerahkan kepadanya seorang suami. Dengan perantaraan suaminya Allah menganugerahkan kepadanya harta dan anak-anak. Lalu dia marah kepada suaminya dan berkata,'aku tidak pernah melihat kebaikan darinya meski sehari pun. $" 60$

2. Wanita Suka Menunda-Nunda Kebaikan

Hadis Rasulullah saw. dalam riwayat Ibnu Ḥibbān:

${ }^{60}$ Aḥmad, Musnad, bab Asma' bin Yazīd, nomor hadis 27602, juz 6, 452 .

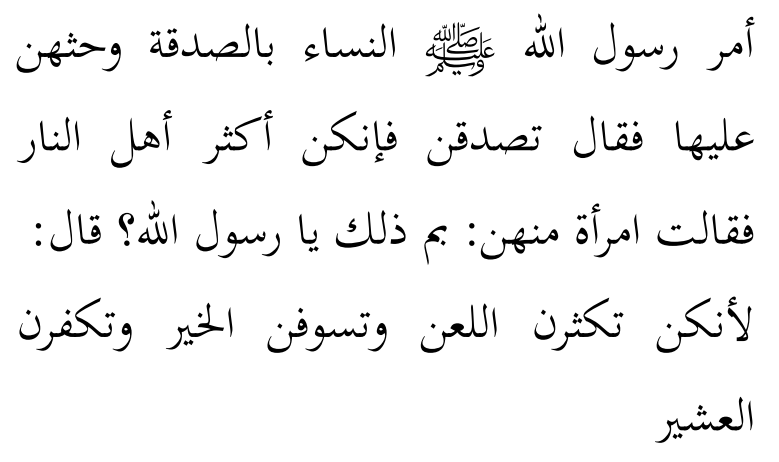

Rasulullah saw memerintahkan para wanita untuk bersedekah, Rasulullah saw. berkata: "Bersedekahlah karena kebanyakan penduduk neraka adalah dari kalangan wanita", kemudian seorang wanita bertanya: "Kenapa wahai Rasulullah." Rasulullah menjawab, "Karena kalian banyak melaknat, mengingkari kebaikan suami dan menunda-nunda kebaikan."61

Sebab-sebab wanita suka menundanunda kebaikan:

a. Terlalu larut dalam perasaan dan emosinya dalam menghadapi peristiwa, sehingga wanita cenderung lamban dalam merespons seruanseruan kebaikan. Anas bin Mālik menuturkan:

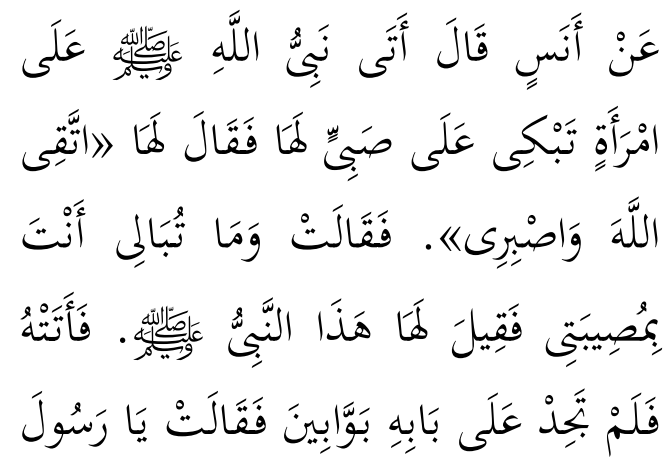

${ }^{61}$ Ibnu Hibbān, Sạhịh, bab Șifah al-Nār wa Ahlihā, nomor hadis 7478 , juz 16, 520 . 


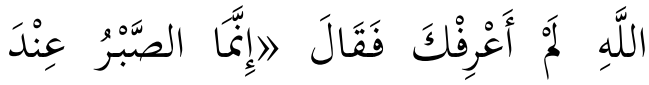

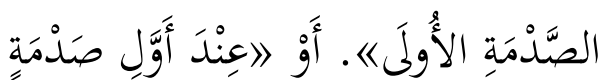

Rasulullah saw melewati seorang wanita yang sedang menangis di sebuah kuburan lalu beliau bersabda: "Bertakwalah kepada Allah dan bersabarlah." Dia berkata, "Menjauhlah dariku, kamu tidak pernah mengalami musibah seperti musibahku ini." Dia belum tahu yang menasehatinya adalah Rasulullah saw. Ketika dikatakan kepadanya bahwa dia adalah Nabi saw. dia mendatangi pintu Nabi saw. dan tidak mendapati seorangpun pengawal di sisi beliau lalu dia berkata: "Maaf, tadi aku belum kenal siapa engkau." Nabi bersabda: "Sesungguhnya sabar itu pada benturan pertama.",62

b. Panjang angan-angan dan kekikiran jiwa

Sebagaimana hadis Rasulullah saw.:

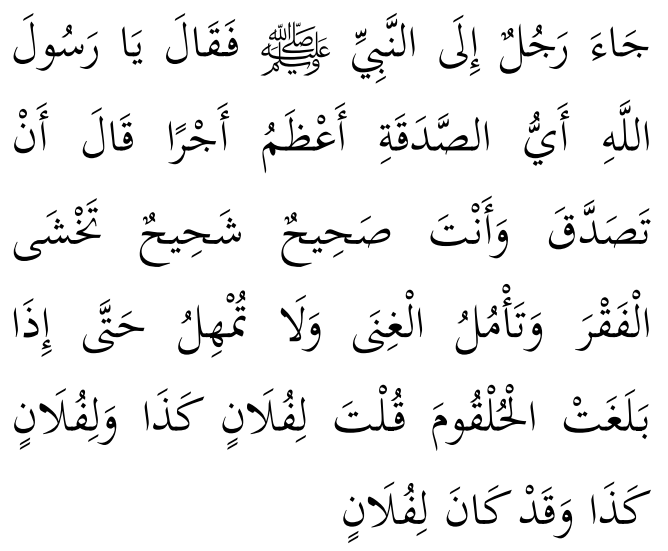

Seorang laki-laki mendatangi Rasulullah saw. seraya bertanya,"Wahai Rasulullah, sedekah apakah yang paling besar pahalanya?" beliau menjawab: "Apabila kamu bersedekah, sedangkan kamu dalam keadaan sehat, kikir, takut fakir, dan

${ }^{62}$ Al-Bukhārī, Șaḥịh, bab ZiyāraH al-Qubūr, nomor hadis 1223 , juz $1,430$. mengangan-angankan kekayaan, janganlah kamu menunda-nunda hingga nyawamu sampai tenggorokan lalu kamu berkata, untuk si fulan sekian, untuk sifulan sekian. "63

c. Menyibukkan diri dengan perniagaan, suka bergosip, dan pamer kekayaan, sebagaimana pesan Rasulullah kepada Alī ra.:

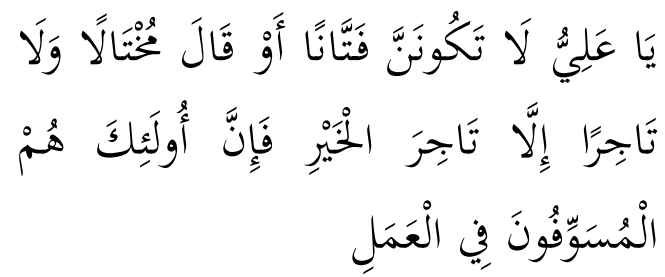

Hai Ali janganlah kamu menjadi tukang fitnah, menjadi orang yang sombong, dan janganlah menjadi pedagang kecuali pedagang kebaikan karena semuanya suka menundamenunda dalam beramal. ${ }^{64}$

d. Sibuk dengan urusan harta dan anakanak, sebagaimana dalam Alquran Q.S. Al-Munāfiqūn: 9-10:

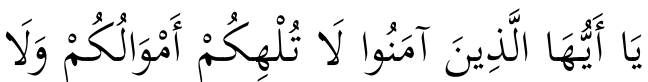

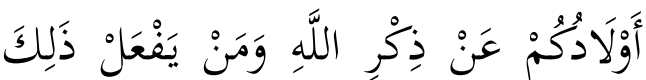

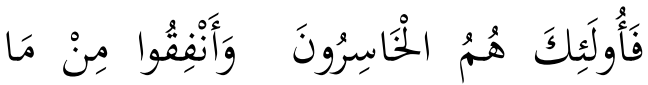

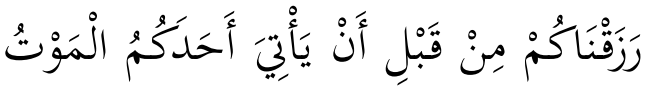

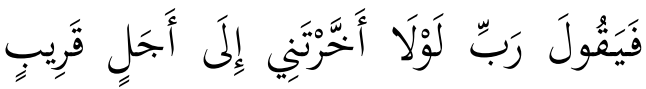

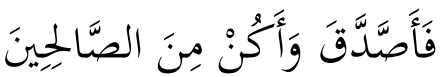

Hai orang-orang yang beriman, janganlah harta-hartamu dan anakanakmu melalaikan kamu dan

${ }^{63}$ Al-Bukhārī, Șaḥịh, bab Ayyi al-Ṣadaqah Afdal, nomor hadis 1353, juz 2, 515.

${ }^{64}$ Aḥmad, Musnad, bab 'Alī bin Abī Ṭālib, nomor hadis 1178 , juz 1, 130. 
mengingat Allah. Siapa yang berbuat demikian maka merka itulah orangorang yang rugi. Dan belanjakanlah sebagian dari apa yang telah kami berikan kepadamu sebelum datang kematian kepada salah seorang di antara kamu lalu dia berkata, "ya Allah, mengapa engkau tidak menangguhkan kematianku sampai waktu yang dekat yang menyebabkan aku dapat bersedekah dan aku termasuk orang-orang yang saleh?"

3. Suka Merengek-Rengek Jika Meminta

Sesuatu

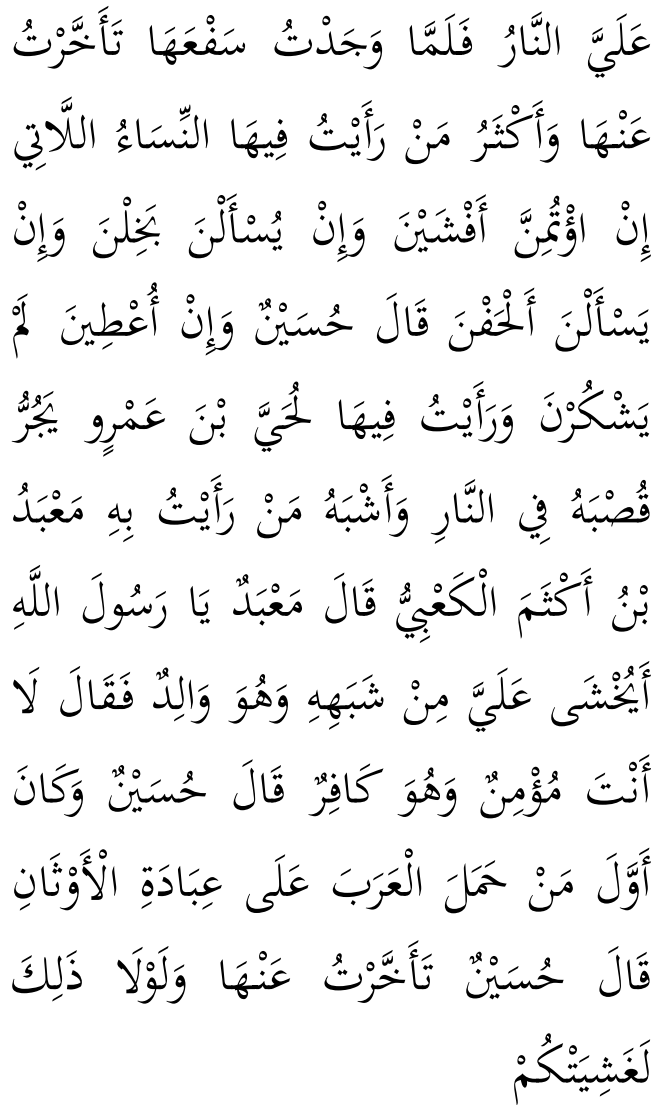

Diperlihatkan kepadaku neraka maka ketika merasakan sengatan panasnya, aku melangkah mundur untuk menjauhinya. Aku melihat kebanyakan penghuninya adalah kaum wanita yang jika dipercaya untuk menyimpan rahasia, mereka mentebarkan, jika meminta, mereka merengek-merengek. Jika diminta, mereka bersikap kikir. Jika diberi, mereka tidak berterima kasih. ${ }^{65}$

4. Wanita Tidak Menyimpan Rahasia

a. Wanita suka membocorkan rahasia, hal ini adalah kebiasaan buruk kecuali tujuan yang baik, sebagimana dalam Alquran Q.S. Al-Nisa’: 114

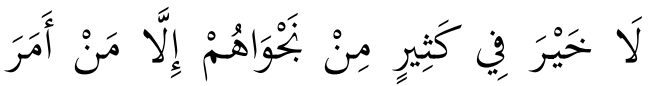

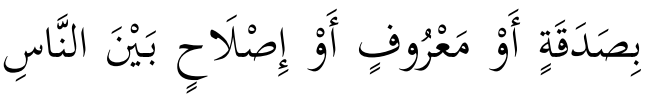

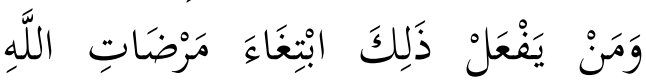

$$
\begin{aligned}
& \text { فَسَوْفَ نُؤْتِيهِ أَجْرًا عَظِيمًا }
\end{aligned}
$$

Tidak ada kebaikan pada kebanyakan bisikan-bisikan mereka kecuali bisikan-bisikan dari orang yang menyuruh memberi sedekah, berbuat makruf, mengadakan perdamaian di antara manusia. Dan siapa yang berbuat demikian karena mencari keridaan Allah maka kelak kami memberi kepadanya pahala yang besar.

b. Wanita suka mengadukan permasalahan yang dihadapi kepada orang yang lain, jika terpaksa mengadukan permasalahan dan membuka rahasia orang lain hendaknya dia datang kepada seorang yang amanah atau mengadukan kepada Allah swt. Allah berfirman Q.S. Al-Mujādalah: 1:

${ }^{65}$ Aḥmad, Musnad, bab Jābir bin 'Abdullāh, nomor hadis 14842, juz 3, 352 . 


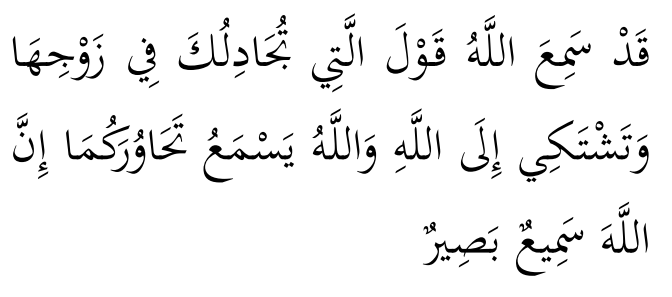

Sesungguhnya Allah telah mendengar perkataan wanita yang mengajukan gugatan kepadamu tentang suaminya dan mengadukannya kepada Allah. Dan Allah mendengar soal-jawab antara kamu berdua. Sesungguhnya Allah Maha Mendengar lagi maha melihat.

c. Kebutuhan wanita untuk berbicara dan mendengar jauh lebih besar daripada kebutuhan pria, oleh karena itu hendaknya bersosialisasi dengan wanita-wanita yang baik, bersemangat dalam mengkaji Islam.

Dari hadis ini dijelaskan bahwasannya yang menyelamatkan wanita dari neraka yaitu dengan memperbanyak sedekah dan istigfar. ${ }^{66}$

Sudah sepatutnya bagi wanita untuk tidak membatasi diri pada sedekah dan istigfar demi menyelamatkan dirinya dari neraka. Dia harus melakukan berbagai bentuk amal saleh, terutama yang paling banyak mendatangkan manfaat bagi kaum muslimin. Sebagian ulama berkata: "Rasulullah saw. memerintahkan sedekah tidak lain karena pada waktu itu banyak kaum muslimin yang membutuhkan bantuan sehingga pada hari itu sedekah

\footnotetext{
${ }^{66}$ Al-'Asqalānī, Fath, juz 6, 325.
} utama.

Kiat-kiat wanita memperbanyak sedekah dan istigfar:

a. Memiliki penghasilan di luar nafkah yang diterima dari suami. ' $\bar{A}$ 'isyah berkata:

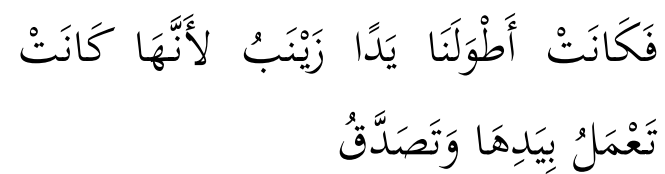

Orang yang paling panjang tangannya di antara kami adalah Zainab, karena dia bekerja dengan kedua tangannya dan banyak bersedekah. ${ }^{67}$

b. Menghemat penggunaan uang belanja dari suami. Jika tidak memungkinkan baginya mencari penghasilan lain hendaknya dia menghemat uang belanja yang diberikan suaminya sehingga dapat menyisakan sebagiannya untuk bersedekah tanpa menzalimi hak-hak suami dan anakanaknya. Rasulullah saw. bersabda:

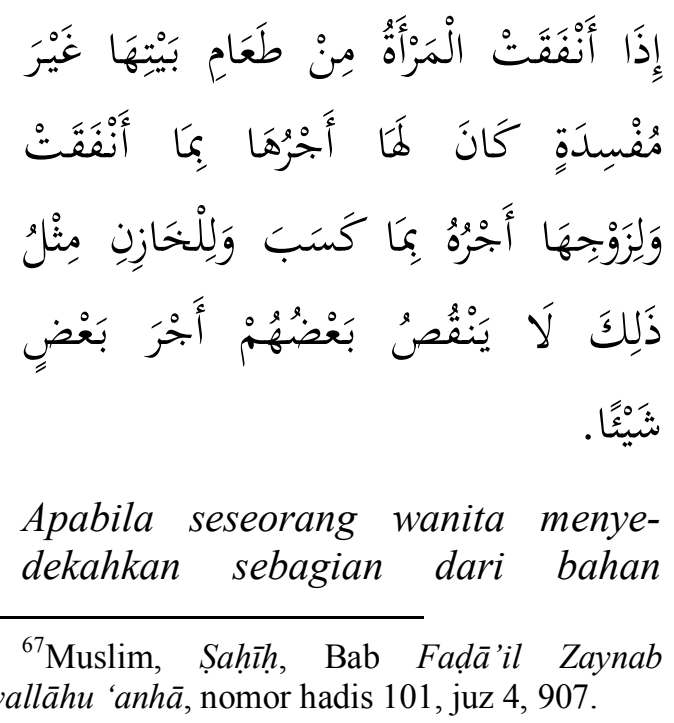
Raḍiyallāhu 'anhā, nomor hadis 101, juz 4, 907. 
makanan yang ada dirumahnya tanpa menimbulkan mafsadah bagi keluarganya, akan dapat pahala atas apa yang disedekahkannya dan suaminya juga mendapatkan pahala atas apa yang diusahakannya. ${ }^{68}$

c. Senantiasa mengingat-ingat keutamaan dan pahala sedekah. Di antaranya hadis:

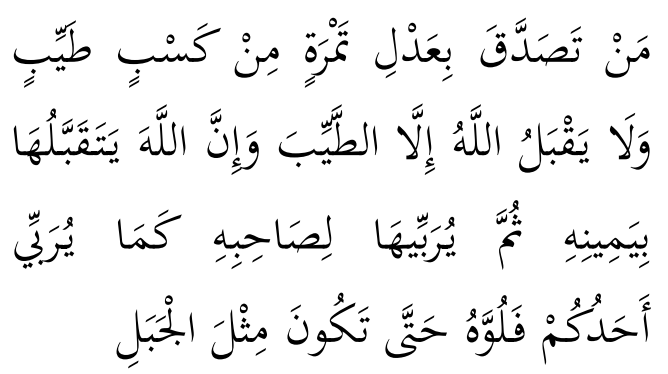

Siapa bersedekah dengan sebuah kurma dari hasil kerja yang baik dan memang tidak akan naik ke sisi Allah kecuali sesuatu yang baik maka Allah akan menerimanya dengan tangan kanannya kemudian memeliharanya untuk pemiliknya, sebagaimana salah seorang diantara kamu memelihara seekor anak kuda sehingga menjadi sebesar gunung.

d. Senantiasa menghadiri majelis taklim

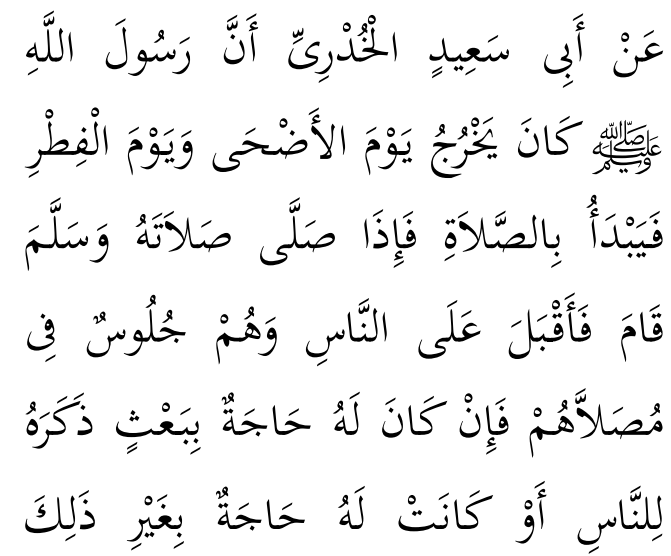

${ }^{68}$ Muslim, Sahīh, bab Ajr al-Khariq al-Amin wa al-Mar'ah, nomor hadis 80, juz 2, 710.
أَمَرَهُمْ بِهَا وَكَانَ يَقُقولُ لاتَصَدَّقُوا تَصَدَّقُوا

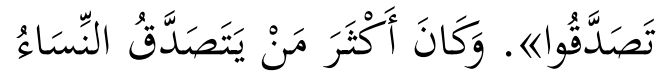

Bahwa Rasulullah saw. menghadap orang-orang yang sedang duduk di tempat salat mereka seraya berkata: "Bersedekahlah, bersedekahlah, bersedekahlah." Ternyata yang paling banyak bersedekah adalah kaum wanita. $^{69}$

e. Memotivasi suami untuk banyak bersedekah

Jika tidak memungkinkan baginya untuk bersedekah dengan harta milik sendiri, hendaknya seorang wanita senantiasa memotivasi suaminya untuk bersedekah dan menjelaskan kepadanya keutamaan dan pahala sedekah. Semoga dengan begitu, suaminya menjadi sadar dan mau bersedekah sehingga dia juga ikut mendapatkan pahalanya. Rasulullah saw. bersabda:

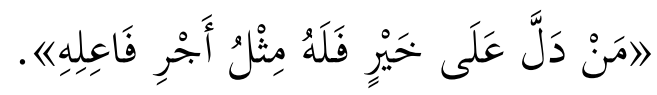

Siapa yang menunjukkan kebaikan kepada seseorang dia akan mendapatkan pahala seperti pahala orang yang melakukannya. ${ }^{70}$

Kiat-kiat agat dapat banyak istighfar:

a. Menyadari betapa banyak dosadosa yang telah dilakukannya 2, 605 .

${ }^{69}$ Muslim, Șaḥịh, bab Șalāh al-'Idayan, juz

${ }^{70}$ Al-Tirmiż̀̄, Sunan, bab al-Dalīl 'alā alKhayr Ka Fà 'ilihi, nomor hadis 2671, juz 5, 41. 
Seorang wanita yang menyadari betapa banyaknya dosa-dosa yang dilakukannya akan merasa takut dan mendorongnya untuk bersegera memohon ampunan kepada Allah agar terbebas dari dosa-dosa tersebut. Rasulullah saw. bersabda:

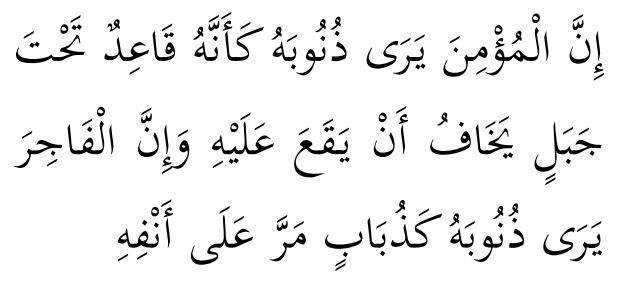

Sesungguhnya seorang mukmin melihat dosa-dosanya seakan-akan berada di dasar gunung dan merasa takut jika gunung itu menimpanya. Sesungguhnya seorang pendurhaka melihat dosadosa seperti seeokor lalat yang hinggap di hidungnya lalu dia menggerakkan tangannya begini sehingga ia pun terbang. ${ }^{71}$

b. Mengingat-ingat keutamaan dan pahala istighfar, sebagaimana Rasulullah bersabda:

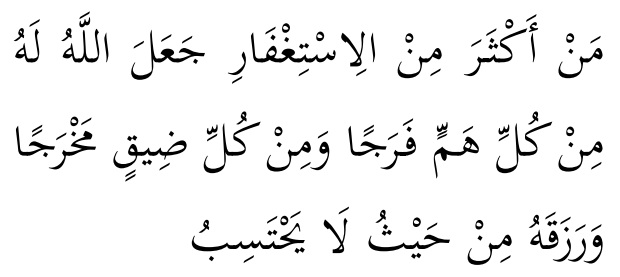

Siapa memperbanyak istigfar, Allah akan menjadikan untuknya kemudahan dari setiap kesusahan serta jalan keluarnya dari setiap kesempitan dan Allah akan

\section{4,658 .}

${ }^{71}$ Al-Tirmiżī, Sunan, nomor Hadis 2497, juz memberinya rezeki dari jalan yang tidak di sangka-sangkanya. ${ }^{72}$

c. Membudayakan istigfar di tengah keluarga, sebagaimana sabda Rasulullah saw.:

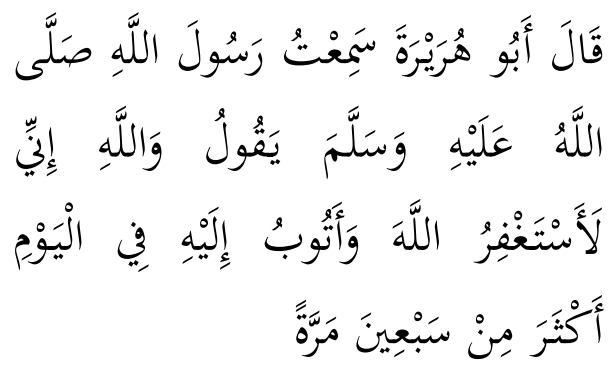

Demi Allah sesungguhnya aku memohon ampunan kepada Allah dan bertaubat kepadanya lebih dari tujuh puluh kali dalam sehari. $^{73}$

\section{Kesimpulan}

Hadis tentang wanita adalah objek yang intens dikomentari oleh para orientalis dan feminis. Mereka mendeskripsikan bahwa Islam mendikotomikan dan menjastifikasi wanita sebagai second public. Hakikatnya Islam telah mengangkat posisi wanita ke derajat lebih tinggi, memberikan kebebasan, kehormatan dan hak pribadinya secara merdeka, derajat dan martabat wanita sesuai dengan fitrahnya dan selaras dengan hak dan kewajiban masing-masing.

Lafaz hadis ini baik tekstual ataupun kontekstual tidak ada mengandung unsur

\footnotetext{
${ }^{72}$ Ahmad, Musnad, bab 'Abdullāh bin Al'Abbās, nomor hadis 2234, juz 1, 248.

${ }^{73}$ Al-Bukhārī, Șahīh, nomor hadis 5948, juz $5,2324$.
} 
misoginis, patriakhi, dikotomi, dan kekurangan wanita, sejatinya itulah merendahkan wanita. Malah sebaliknya, kelebihan yang Allah berikan kepada memotivasi wanita untuk semangat mereka, agar saling melengkapi di antara menuntut ilmu, beribadah, taqarrub, sepasang manusia, laki-laki dan wanita. bersedekah dan menjaga lisan. Di balik

\section{Daftar Pustaka}

Abū Syuqqah, 'Abd al-Ḥalīm Muhammad. Taḥrīr al-Mar'ah fì 'Asr al-Risālah. Cet. 7. Kairo: Dār al-Qalām, 2011.

Arani, Amiruddin. Tubuh Seksualitas dan Kedaulatan Wanita. Cet. 1. Jakarta: Rahima, 2002. al-‘Asqalānī, Ibnu Hajar. Fatḥ al-Bārī. Beirut: Dār al-Fikr, t.th.

al-'Ayn̄̄, Badr. 'Umdah al-Qārī. Mesir: Multaqā Aḥl al-Ḥadīs, 2006.

al-Bukhārī, Abū 'Abdullāh Muḥammad bin Ismā'īl bin Ibrāhīm bin al-Mugīrah al-Ju'fī. AlJāmi' al-Musnad al-Ṣaḥ̄h al-Mukhtaṣar min Umūri Rasūl ṣallallāhu 'Alayhi wa Sallam min Sunanihi wa Ayyāmihi. Beirut: Dār Ibnu Kas̀īr, 1987.

Ḥusayn, 'Āqilah.al-Mar'ah al-Muslimah wa al-Fikri al-Istisyrāqī. Beirut: Dār Ibnu Ḥazm, 2004.

'Ibnu 'Abd al-Bārr, Tamhīd. Magribi: Wizārah 'Umūm al-Awqāf wa al-Syu'ūn al-Islāmiyyah, $1387 \mathrm{M}$.

Ibnu Baṭal, Syarḥ Șaḥịh al-Bukhārī. Juz 1. Riyad: Maktabah al-Rusyd, 2002.

'Imārah, Muḥammad. Al-Taḥrīr al-Islāmi li al-Mar'ah al-Rad 'Alā Syubhāt al-Gulāh. Kairo: Dār al-Syurūq, 2001.

al-Istambulī, Mạ̣mūd Mahdī dan Musțafā Abū Nașr al-Asyalabī. Nisā' Hawla Rasūl (Mereka Adalah Para Sahabiyyah). Cet. 10. Solo: al-Tibyan, 2010.

Ja'far, Muhammad Anis Qasim. Al-Huqūq al-Siyāsiyah li al-Mar'ah fĩ al-Islām wa al-Fikr wa al-Tasyrì' al-Mu'āṣir (Perempuan dan Kekuasaan Menelusuri Hak Politik dan Persoalan Gender dalam Islam). Jakarta: Amzah, 2008.

Kamal, Abdul Malik. Fiqh al-Sunnah li an-Nisa' (Ensiklopedi Fiqih Wanita). Cet. 2. Depok: Pustaka Khazanah Fawa'id, 2017.

Masrur, Ali. Teori Common Link G.H.A. Juynboll. Cet.1. Yogyakarta: Lkis, 2007.

Matnur, Abdul Aziz. Jangan Rendahkan Wanita. Jakarta: Pustaka al-Kausar, 2009. 
Mernissi, Fatimah. Beyond the Veil: Male-Female Dynamics in Modern Muslim Society (Beyond The Veil Seks dan Kekuasaan Dinamika Pria dan Wanita dalam Masyarakat Muslim Modern), terj. Mahsyur Abadi. Cet. 1. Surabaya: Al-Fikr, 1997.

, The Forgotten Queens of Islam (Ratu-Ratu Islam Yang Terlupakan), terj. Rahma Astute dan Enna Hadi. Cet. 1. Bandung: Mizan, 1994.

Al-Mubārakfūrī. Tuḥfah al-Aḥwazī, Juz 7. Beirut: Dār al-Kutub al-Ilmiyyah, t.th.

Al-Nawawī, al-Minhāj. Juz 9. Beirut: Dār Iḥya’ al-Turāì al-Arabī, 1392 H.

al-Naysābūrī, Abū al-Ḥusayn Muslim bin al-Ḥajjāj al-Qusyayrī. Saḥịh Muslim. Juz 1 Beirut:

Dār Ihyā' al-Turās̀ al-'Arabī, t.th.

Nursyam, Fakhruddin. Hadis-Hadis Pilihan Untuk Wanita. Bandung: Sigma Publishing, 2011.

Qazan, Shalah. Naḥwa Fikr Nisā’̄ Harakiyyin Munaz̧zam (Membangun Gerakan Menuju Pembebasan Perempuan). Solo: Intermedia, 2001.

al-Qazwīn̄̄, Muḥammad bin Yazīd Abū 'Abdullāh. Sunan Ibnu Mājah. Juz 2. Beirut: Dār alFikri, t.th.

Raliby, Osman. Kamus Internasional. Cet. 2. Jakarta: Bulan Bintang, 1982.

Sa'dawī, Amrū 'Abd al-Karīm. Qaḍ̂ȳà al-Mar'ah fì Fiqh al-Qarḍ̂̄wī (Wanita Dalam Fikih al-Qaradhawi). Jakarta: Pustaka al-Kautsar, 2009.

Saqar, 'Ațiyah. Fatāwa wa Ahkām lil Mar'ah al-Muslimah. Kairo: Maktabah Wahbah, 2002.

Subhan, Zaitunah. Tafsir Kebencian; Studi Bias Gender dalam Studi al-Quran. Yogyakarta: LKiS, 1999.

al-Sya'rawi, Mutuwalli. Figh al-Mar'ah al-Muslimah (Fikih Perempuan Busana dan Perhiasan, Sampai Wanita Karier). Cet. 3. Jakarta: Amzah, 2009.

Al-Syawkānī, Nayl al-Auțār. Mesir, Idārah at-Ṭabā'ah al-Munīrah, t.th.

al-Syaybān̄̄, Aḥmad bin Hanbal Abū Abdullāh Musnad Ahmad bin Hanbal. Kairo: Mu'assasah Qurțubah, t.th.

al-Tirmiżī, Muhammad bin 'Īsā Abū 'Īsā. Al-Jāmi ' al-Șaḥ̄h Sunan al-Timiżī. Beirut: Dār alIhya' al-Turaṡ al-Arabī, t.th.

Umar, Nasaruddin. Argumen Kesetaraan Jender. Cet. 2. Jakarta: Paramadina, 2001. al-Uwayyid, Muhammad Rasyid. Aḥ̄àìs al-Mar'ah fì Ṣaḥihayn (Hadis-Hadis Perberdayaan Wanita dari Kitab Sahih Bukhari dan Muslim). Surabaya: Pustaka Yassir, 2014. 
WANITA MAYORITAS DI NERAKA, IMPERFEC AKAL DAN AGAMA

Wadud, Amina. Quran and Women: Reading the Sacred Text From a Woment's Prespective (Quran Menurut Wanita, Membaca Kitab Suci Dengan Semangat Keadilan), terj. Abdullah Ali. Cet. 1. Jakarta: Serambi, 2006. 